\title{
Quinolines as Chemotherapeutic Agents for Leishmaniasis
}

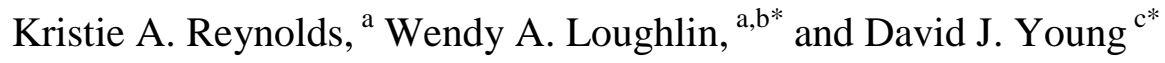 \\ ${ }^{a}$ Eskitis Institute for Cell and Molecular Therapies, Nathan Campus, Griffith University, Brisbane, QLD, 4111, \\ Australia \\ ${ }^{b}$ School of Biomolecular and Physical Sciences, Nathan Campus, Griffith University, Brisbane, QLD, 4111, \\ Australia \\ ${ }^{c}$ Faculty of Science, Universiti Brunei Darussalam, Jln Tungku Link, Gadong BE1410, Brunei Darussalam. Email: \\ david.young@ubd.edu.bn
}

Abstract: The development of leishmanicidal quinolines and their in vitro (promastigote and amastigote) and, where applicable, in vivo activities are reviewed. This survey provides a direct comparison of bioactivity across different species (e.g. L. donovani, L. amazonensis, L. chagasi, L infantum), and in different animal models (e.g. L. donovani Balb/c mice and $L$. donovani infected hamsters). The progress of selected quinolines through pre-clinical development and phase I/II trials, and the lead quinoline drugs sitamaquinine and Imiquimod, are discussed in conjunction with delivery systems and combination therapies.

\section{Introduction}

Leishmaniasis is a group of parasitic diseases spread by two genera of sandfly and causes symptoms ranging from skin and mucous-membrane lesions (cutaneous, CL or mucocutaneous leishmaniasis, MCL) to fatal organ infestation (visceral leishmaniasis, VL). The Leishmania parasite exists in the promastigote form in the sandfly vector which is first ingested by neutrophils [1] and then by macrophages in the human host or animal reservoir [2]. It then transforms into the non-flagellated amastigote, multiplies, ruptures the macrophage and circulates to infect fresh cells. This infection may be localized in cutaneous tissue (CL) resulting in chronic lesions which may selfheal over time. Alternatively, infection of mucosae (MCL) can lead to severe tissue destruction and disfigurement while infection of the spleen, liver and bone marrow (VL) is usually fatal if not treated [3].

Leishmaniasis is endemic in many developing countries from Central and South 
America to southern Europe, the Middle East, Africa and South-West Asia and it is likely that this range will spread with altering climate patterns [4]. The number of cases has increased sharply over the last 10 years with an estimated 12 million patients. Most of these developing countries are also struggling with endemic HIV/AIDS and there has been a sharp increase in co-infection rates [5]. Both diseases attack immune cells increasing the infection risk of the other, the probability of relapse and clinical progression in both. The availability of highly active antiretroviral therapy (HAART) in Europe has led to far fewer new leishmaniasis infections in HIV-positive patients, but this treatment is only sparsely available in the majority of developing countries.

To date, the treatment of leishmaniasis has relied on toxic compounds and / or established drugs originally developed for other diseases. The first chemotherapy for newly diagnosed patients is still antimony (V) based drugs in most countries [6]. These include sodium stibogluconate (Pentostan ${ }^{\circledR}$ ) and meglumine antimoniate $\left(\right.$ Glucantime $^{\circledR}$ ) which are complex mixtures of oligomeric sugar - metal complexes, rather than discreet molecules [7]. The antimony (V) is reduced to more toxic trivalent antimony in the parasite although there are competing theories concerning the leishmanicidal mechanism of these compounds [8]. The antimonials require up to 28 days of parenteral administration and significant acquired drug resistance has emerged. The more expensive pentamidine and amphotericin B is usually effective in these cases, but still require injection or infusion and are beset with side-effects $[9,10]$. The anti-cancer agent Miltefosine (hexadecylphosphocholine) is the first effective oral drug, although it is teratogenic, still moderately expensive and can lead to resistance if treatment is incomplete $[10,11]$.

In the quest for less toxic and less expensive chemotherapies, a large number of plant extracts and plant-derived natural products have been tested for anti-protozoal activity [12]. Most of the major classes of natural products have representatives with in vitro or in vivo activity against Leishmania, including phenolic compounds, terpenoids, quinones and alkaloids. Arguably, the most promising candidates belong to the latter family which include the anti-malarial quinine, an aminoquinoline that inhibits choline transport in L. major promastigotes [13]. The 8-aminoquinoline sitamaquine is an orally available drug that showed considerable promise in preclinical models, 
but yielded mixed results in clinical trials, exhibiting variable cure rates and nephrotoxicity [14]. Structurally simpler 2-substituted quinolines, some isolated from the Bolivian medicinal plant Galipea longiflora (Rutaceae), show potent oral activity in a murine model of CL [15,16] and VL [17].

Simple quinolines could be important leads in the development of affordable, orally available treatments for leishmaniasis. Current chemotherapies and recent advances have been broadly reviewed elsewhere $[18,19]$. Our purpose here is to survey the structure activity relationship (SAR) of leishmanicidal quinoline analogues. This task is complicated by the different ways of quantifying and reporting leishmanicidal activity. Substituted quinolines have been investigated in clinical, in vivo and / or in vitro growth inhibition or related studies using promastigote and / or amastigote forms of between one and five of the $c a 32$ species of Leishmania and employing a variety of measures from the commonly used $\mathrm{IC}_{50}$ to the esoteric $\mathrm{G}$-index $\left(\mathrm{G}=\mathrm{SD}_{90}\right.$ for meglumine antimoniate / $\mathrm{SD}_{90}$ for test compound). Direct comparison between studies is therefore not always meaningful, but a qualitative meta-analysis does allow some global trends to be inferred.<smiles>c1ccc2ncccc2c1</smiles>

Quinoline<smiles>COc1cc(NC(C)CCCN)c2ncccc2c1</smiles>

Primaquine<smiles>CC[C@H]1CN2CC([C@H](O)c3ccnc4ccc(OC)cc34)CC1C2</smiles>

Quinine<smiles>CCCNCCCCCCNc1cc(OC)cc2c(C)ccnc12</smiles>

Sitamaquine<smiles>CCN(CC)CCCC(C)Nc1ccnc2cc(Cl)ccc12</smiles>

Chloroquine<smiles>OC(c1cc(C(F)(F)F)nc2c(C(F)(F)F)cccc12)[C@H]1CCCCN1</smiles>

Mefloquine

Fig. (1). Structures of quinoline and the anti-parasitic aminoquinolines, quinine, sitamaquine, primaquine, chloroquine and mifloquine.

\section{Monosubstituted Quinolines}


A series of 2-substituted quinoline alkaloid natural products isolated from a Bolivian medicinal plant, G. longiflora, used to treat CL ulcers demonstrated potent activity against a mouse model of New World CL [15]. These structurally simple quinolines show potent oral activity against both CL [15,16] and VL [17]. A variety of substitutions at the 2-position of the quinoline ring have been extensively studied because of the potent activity seen with isolated three - five carbon chain quinoline natural products (2-n-propylquinoline (1) , 2-(1, 2-trans-epoxypropyl) quinoline (chimanine D) (2) 2-(E)-prop-1-enylquinoline (chimanine B) (3) and 2-npentylquinoline (4)) which show greater potency than $\mathrm{N}$-methylglucamine antimonate against L. amazonensis, L. braziliensis and L. donovani [20].

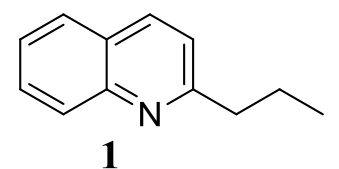

$\mathrm{IC}_{50}=50 \mu \mathrm{g} / \mathrm{mL}$<smiles>C/C=C/c1ccc2ccccc2n1</smiles>

3

L. inf antum $\mathrm{IC}_{50}=12 \mu \mathrm{M}$

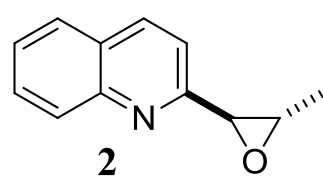

$\mathrm{IC}_{50}=25 \mu \mathrm{g} / \mathrm{mL}$

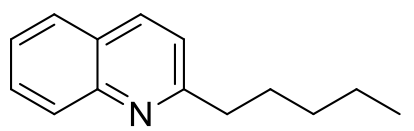

4

L. inf antum $\mathrm{IC}_{50}=16 \mu \mathrm{M}$

Substitution of an unsaturated group at the 2-position (e.g. $\alpha, \beta$-unsaturated aldehyde or allylic alcohol (5-14)) increased in vitro activity relative to the unexpectedly potent 2-n-propylquinoline $[21,22]$. Compounds $\mathbf{5}, \mathbf{8}, \mathbf{9}, \mathbf{1 1}, \mathbf{1 2}$ showed significant inhibition of L. amazonensis and L. infantum amastigote proliferation in macrophages [23]. Analogues 5 and 9 had similar bioactivities $\left(\mathrm{IC}_{50}=3.6,3.2 \mu \mathrm{M}\right.$ respectively) against resistant strains of L. donovani. Both $\mathbf{5}$ and $\mathbf{9}$ were approximately 3 times more active than miltefosine against the HePC-R line and 40 times more active then sitamaquine on the Sita-R line and all other Leishmania tested cell lines [24]. Increasing the chain length of the 2-substituent resulted in a dramatic decrease in leishmanicidal activity. 2-But-2-enenitrile and 2-hex-2-ene analogs, for example exhibited in vitro $\mathrm{IC}_{50}=<30$ $\mu \mathrm{M}$ when screened against $L$. donovani, L. amazoniensis and L. infantum [17,25].

Saquinavir (15), a 2-substituted aminoquinoline inhibits $L$. major parasite growth by $17 \%$ to $65 \%$ over 2 to 3 days in a dose-dependent manner. However, inhibition of $L$. 
infantum, parasite growth was only $5 \%$ to $34 \%$ over the same period with irreversible leishmanicidal activity [26].<smiles>[R]c1ccc2ccccc2n1</smiles>

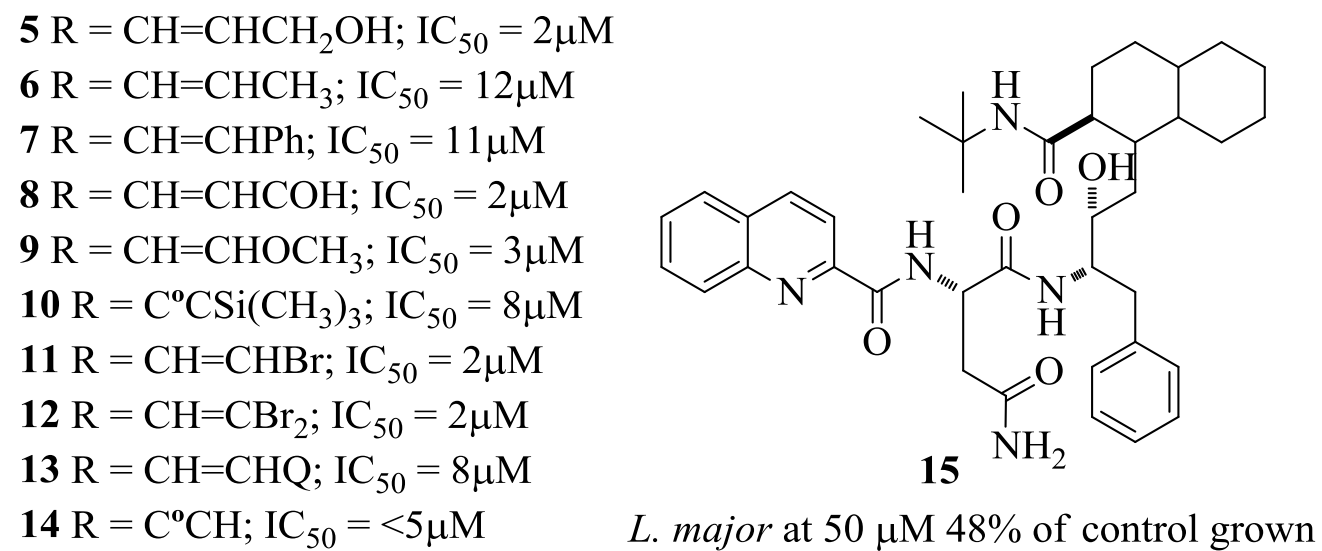

By comparison, 3-substituted quinolines demonstrate limited in vitro activity against Leishmania species of all disease types investigated (L. amazonensis, $L$. infantum, $L$. major, L. mexicana and L. donovani) [23,27]. Investigations of 3-substituted bisquinolines or halogenated analogues indicated that these compounds were either inactive or possessed significant cytotoxicity against host cells [23,27]. The corresponding 5- and 6-substituted quinolines have received less attention. Zosuquidar, a P-glycoprotein inhibitor, is a promising reversing agent against Leishmania parasites. The 5-substituted quinoline exhibited 16 - 30\% growth inhibition of $L$. tropica at $1 \mu \mathrm{M}$ [28]. Similarly, the 6-substituted quinolines demonstrated some limited activity against $L$. amazonensis and $L$. infantum $\left(\mathrm{IC}_{50}=\right.$ $>200 \mu \mathrm{M})[23]$.

Various 8-sulfonamido and boronate quinolines exhibit particularly high in vitro activity against Leishmania parasites [29,30]. The $\mathrm{IC}_{50}$ values of 8quinolinylsulfonamides range from 0.45 to $2.99 \mu \mathrm{M}$ and 2.12 to $2.85 \mu \mathrm{M}$ for $L$. chagasi and L. amazonensis promastigotes respectively. Compounds 16, 17 and 18 were twice as active as the 'gold standard' amphotericin B against L. chagasi. Compounds 19, 20 and 21 also demonstrated significant activity ranging from $\mathrm{IC}_{50}=$ 6.27 to $14.47 \mu \mathrm{M}$ and 2.18 to $13.96 \mu \mathrm{M}$ against L. amazonensis and L. chagasi 
respectively [29]. The introduction of a nitro group or fluorine atom at the 4-position of the phenyl moiety induced a loss of activity against Leishamania promastigotes. Cell infection by L. amazonensis decreasing by $67.1 \%$ at $5 \mu \mathrm{M}$ for $\mathbf{1 6}$ and $82.1 \%$ at $25 \mu \mathrm{M}$ for 19 [29].<smiles>[R]S(=O)Nc1cccc2cccnc12</smiles>

$16 \mathrm{R}=3$-bromo-2-chloropyridine; $\mathrm{IC}_{50}=2.25 \mu \mathrm{M}$

$17 \mathrm{R}=\mathrm{Ph}-\mathrm{Ph} ; \mathrm{IC}_{50}=2.18 \mu \mathrm{M}$

$18 \mathrm{R}=4$-dimethylnaphthalen-1-amine ; $\mathrm{IC}_{50}=3.53 \mu \mathrm{M}$

$19 \mathrm{R}=p$-propylbenzene; $\mathrm{IC}_{50}=13.96 \mu \mathrm{M}$

$20 \mathrm{R}=3,5$-difluorobenzene; $\mathrm{IC}_{50}=0.45 \mu \mathrm{M}$

$21 \mathrm{R}=p$-bromobenzene; $\mathrm{IC}_{50}=2.99 \mu \mathrm{M}$

$22 \mathrm{R}=2$,3-dibromothiophene; $\mathrm{IC}_{50}=0.53 \mu \mathrm{M}$

The 8-boronic ester substituted quinolines 23-28 contain varying side chains attached to the quinoline moiety via a boronic acid linker. These side chains consist of vinyl or aryl (phenyl, furanyl, pyridinyl or dihydrooxazolyl) substituents. Aryl components were further substituted with amines, halogens or cyano groups [30]. Compounds 23 and 24 displayed $\mathrm{IC}_{50}$ values of 0.02 and $0.07 \mu \mathrm{g} / \mathrm{ml}$ respectively. Over 70 similar compounds were tested with $\mathrm{IC}_{50}$ values ranging from $0.20-0.80 \mu \mathrm{g} / \mathrm{ml}$ against $L$. donovani amastigotes cultured from golden hamsters. Growth inhibition was also observed with Plasmodium falciparum, Trypanosoma brucei rhodesiense and T. cruzi [30]. Bisquinoline (1,1'-Bis-[(8-quinolyl)oxy]methane) was also tested for its antiparasitic activity against intracellular $L$. donovani promastigotes and amastigotes and displayed an $\mathrm{IC}_{50}$ of 2.4 and $2.3 \mu \mathrm{M}$ respectively. Intraperitoneal (IP) treatments against $L$. donovani-BALB/c mice exhibited reduced splenic and liver parasite loads of $89 \%$ and $91 \%$ respectively [31]. 
<smiles>[R]B([R])Oc1cccc2cccnc12</smiles>

$23 \mathrm{R}=2-\mathrm{F}-4-\mathrm{Cl}-\mathrm{Ph}, \mathrm{R}^{\prime}=3-\mathrm{F}-\mathrm{Ph} ; \mathrm{IC}_{50}=0.02 \mu \mathrm{g} / \mathrm{ml}$

$24 \mathrm{R}=3-\mathrm{Me}-4-\mathrm{Cl}-\mathrm{Ph}, \mathrm{R}^{\prime}=4-\mathrm{NC}-\mathrm{Ph} ; \mathrm{IC}_{50}=0.07 \mu \mathrm{g} / \mathrm{ml}$

$25 \mathrm{R}=3-\mathrm{NC}-4 \mathrm{~F}-\mathrm{Ph}, \mathrm{R}^{\prime}=$ vinyl; $\mathrm{IC}_{50}=0.19 \mu \mathrm{g} / \mathrm{ml}$

$26 \mathrm{R}=3,5$-di-F-Ph, $\mathrm{R}^{\prime}=$ vinyl; $\mathrm{IC}_{50}=0.21 \mu \mathrm{g} / \mathrm{ml}$

$27 \mathrm{R}=3-\mathrm{NC}-\mathrm{Ph}, \mathrm{R}^{\prime}$ vinyl $=; \mathrm{IC}_{50}=0.25 \mu \mathrm{g} / \mathrm{ml}$

$28 \mathrm{R}=4-\mathrm{Cl}-\mathrm{Ph}, \mathrm{R}^{\prime}=4-\mathrm{OMe}-3-\mathrm{F}-\mathrm{Ph} ; \mathrm{IC}_{50}=0.29 \mu \mathrm{g} / \mathrm{ml}$

\section{Disubstituted Quinolines}

Some 2,3-substituted indolylquinoline derivatives exhibit significant anti-leishmanial activity. Indolylquinolines $\mathbf{2 9}, \mathbf{3 0}$, and $\mathbf{3 1}$ bearing a reactive $\alpha$-chloroacetamide group inhibit the growth of $L$. donovani promastigotes in vitro and are cytotoxic to both the promastigote and amastigote forms of the parasite, while the non-chlorinated $\mathbf{3 2}$ was inactive [32]. Derivatives 29, 30, and 31 were also effective in eliminating $L$. donovani amastigotes from $\mathrm{BALB} / \mathrm{c}$ mouse peritoneal macrophages in vitro [32]. Recently, 30 was shown to reduced the splenic and liver parasite burdens in $L$. donovani-infected hamsters by $>93.0 \%$ [33]. In addition, both $\mathbf{3 0}$ and the less reactive 32 proved to be 'dual inhibitors' of type I and II DNA topoisomerases of L. donovani, suggesting the possibility of rational drug design [34]. By contrast, simple 2,3disubstituted quinolines had no leishmanicidal activity in the assays employed. 2Methyl-3-carboxyquinoline, for example, had an in vitro $\mathrm{IC}_{50}=>30 \mu \mathrm{g} / \mathrm{mL}$ against $L$. donovani [35].<smiles>[R]Nc1ccccc1Cc1nc2ccccc2cc1-c1c[nH]c2ccccc12</smiles>

$29 \mathrm{R}=\mathrm{H}$; GI $40 \%(5 \mathrm{mg} / \mathrm{L}$, day 6$)$

$30 \mathrm{R}=\mathrm{C}(\mathrm{O}) \mathrm{CHCl}_{2} ; \mathrm{GI} 40 \%(5 \mathrm{mg} / \mathrm{L}$, day 6$)$

$31 \mathrm{R}=\mathrm{C}(\mathrm{O}) \mathrm{CH}_{2} \mathrm{Cl} ; \mathrm{GI} 40 \%(5 \mathrm{mg} / \mathrm{L}$, day 6$)$

$32 \mathrm{R}=\mathrm{C}(\mathrm{O}) \mathrm{CH}_{3}$; $\mathrm{NA}$ 
Studies of 2,4-disubstituted quinolines are limited to 4-methoxy or carboxy quinolines with a 2-alkyl or aryl group. These derivatives were again isolated from the stem bark of G. longiflora, the extract of which is used as a traditional medicine for the treatment of CL [36]. The most potent compound was 33, which displayed in vitro activity against L. donovani, L. amazonensis, and L. braziliensis. Compounds 34, 35 and 36 demonstrated limited in vitro activity against $L$. donovani and $L$. infantum [37]. The novel 2,4-disubstituted quinoline 2-(2-methylquinolin-4-ylamino)- $N$ phenylacetamide, also inhibited $L$. donovani in a dose dependent manner at a concentration of $5.0 \mu \mathrm{g} / \mathrm{ml}$, inhibiting parasite growth by $66 \%$ on the $2^{\text {nd }}$ day and by $95 \%$ by the $7^{\text {th }}$ day of the assay [38].

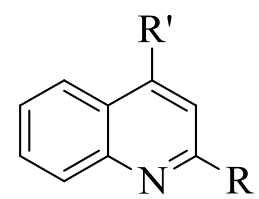

$33 \mathrm{R}^{\prime}=\mathrm{OCH}_{3}, \mathrm{R}=\mathrm{Ph} ; \mathrm{IC}_{50}=30 \mu \mathrm{g} / \mathrm{mL}$

$34 \mathrm{R}^{\prime}=\mathrm{COOH}, \mathrm{R}=p$-PhOMe; $\mathrm{IC}_{50}=22 \mu \mathrm{g} / \mathrm{mL}$

$35 \mathrm{R}^{\prime}=\mathrm{COOH}, \mathrm{R}=p-\mathrm{PhOH} ; \mathrm{IC}_{50}=>17 \mu \mathrm{g} / \mathrm{mL}$

$36 \mathrm{R}^{\prime}=\mathrm{COOH}, \mathrm{R}=p-\mathrm{PhCl} ; \mathrm{IC}_{50}=>18.2 \mu \mathrm{g} / \mathrm{mL}$

The 2, 6-disubstituted $\mathbf{3 7}, \mathbf{3 8}$ and $\mathbf{3 9}$ exhibited relatively good in vitro activity against promastigotes of $L$. chagasi. These quinolines were more active against promastigotes than amastigotes but less active than the reference amphotericin $\mathrm{B}\left(\mathrm{IC}_{50}=0.01 \mu \mathrm{M}\right.$, $\left.\mathrm{IC}_{90}=0.03 \mu \mathrm{M}\right)[39]$.

2,8-Disubstituted quinolines have received limited attention. 2-Substituted quinolin-8ols were investigated in bioassays of intracellular amastigotes of L. amazonensis and L. infantum but were cytotoxic towards the host cell macrophages [23]. 2-((Z)-Prop-1enyl)quinolin-8-ol was active $\left(\mathrm{IC}_{50}=14 \mu \mathrm{M}\right)$ against $L$. infantum but other 2substituted quinolin-8-ol derivatives showed no inhibition against selected Leishmania strains [23]. 


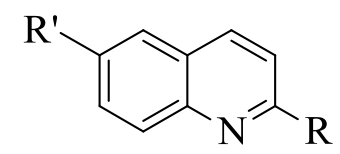

$37 \mathrm{R}^{\prime}=\mathrm{OMe}, \mathrm{R}=2$-furanyl; $\mathrm{IC}_{50}=60 \mu \mathrm{M}$

$38 \mathrm{R}^{\prime}=\mathrm{Me}, \mathrm{R}=2$-thiophene; $\mathrm{IC}_{50}=64 \mu \mathrm{M}$

$39 \mathrm{R}^{\prime}=\mathrm{Cl}, \mathrm{R}=m$-toluidine; $\mathrm{IC}_{50}=53 \mu \mathrm{M}$

$40 \mathrm{R}^{\prime}=\mathrm{CH}_{3}, \mathrm{R}=\mathrm{CH}=\mathrm{CHC}(\mathrm{O}) \mathrm{OCH}_{3} ; \mathrm{IC}_{50}=8 \mu \mathrm{M}$

Bisquiolines 41-44 displayed significant activity against $L$. donovani intracellular promastigotes and amastigotes. All of the tested bisquinolines, except compound $\mathbf{4 2}$, displayed activities comparable to pentamidine $\left(\mathrm{IC}_{50}=2.1\right.$ and $2.8 \mu \mathrm{g} / \mathrm{mL}$, promastigotes and amastigotes, respectively). These promising in vitro results justified a trial of IP administration ( $12.5 \mathrm{mg} / \mathrm{kg}$ ) using $L$. donovani-BALB/c mice. Bisquinolines $\mathbf{4 3}$ and $\mathbf{4 4}$ resulted in significant reductions in parasite burden in spleen (73.5, $82 \%$; control $57 \%)$ and liver $(78,88.5 \%$; control $60 \%)$ relative to the control, sodium antimony gluconate [31].

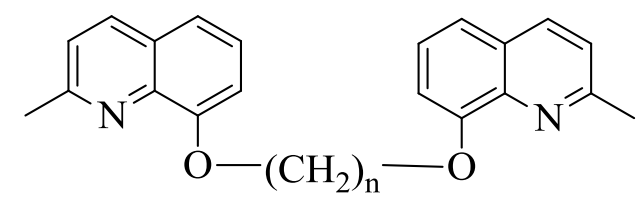

$41 \mathrm{n}=1, \mathrm{IC}_{50}(\mu \mathrm{g} / \mathrm{mL})=3.4$ (promastigote); 2.9 (amastigote)

$42 \mathrm{n}=3, \mathrm{IC}_{50}(\mu \mathrm{g} / \mathrm{mL})=13.5$ (promastigote); 10 (amastigote)

$43 \mathrm{n}=4, \mathrm{IC}_{50}(\mu \mathrm{g} / \mathrm{mL})=3.2$ (promastigote); 2.7 (amastigote)

$44 \mathrm{n}=6, \mathrm{IC}_{50}(\mu \mathrm{g} / \mathrm{mL})=2.8$ (promastigote); 2.4 (amastigote)

4,7-Disubstituted quinolines based on the anti-malarial chloroquine display potent in vitro anti-leishmanial activity. The cinchona alkaloid-like 7-chloro quinolines 45-47 inhibited $L$. donovani promastigote growth at concentrations comparable to that of the chemotherapeutic agent pentamidine $(2.8 \mu \mathrm{g} / \mathrm{mL})$ but were less potent than amphotericin $\mathrm{B}\left(\mathrm{IC}_{50}=0.18 \mu \mathrm{g} / \mathrm{mL}\right)$ in the same assay [40]. Similar 7-chloro quinolines 48-51 displayed moderate potency against $L$. major amastigotes $\left(\mathrm{IC}_{50}=1.5\right.$ $\mu \mathrm{g} / \mathrm{mL}$ ) [41]. Analogue 52 exhibited a minimum effective concentration (MEC) of 1050 and $10 \mu \mathrm{g} / \mathrm{ml}$ respectively against $L$. mexicana and L. tropica major amastigotes. 


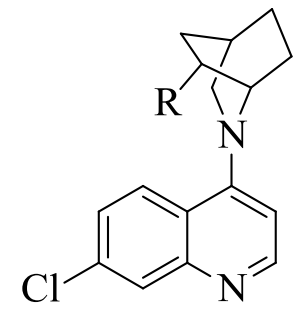

$45 \mathrm{R}=\mathrm{CNH}_{2} \mathrm{C}_{2} \mathrm{H}_{6} ; \mathrm{IC}_{50}=1.9 \mu \mathrm{M}$

$46 \mathrm{R}=\mathrm{CNH}_{2} \mathrm{C}_{4} \mathrm{H}_{10} ; \mathrm{IC}_{50}=3.8 \mu \mathrm{M}$

$47 \mathrm{R}=\mathrm{CH}_{2} ; \mathrm{IC}_{50}=3.0 \mu \mathrm{M}$<smiles>[R]c1ccnc2cc(Cl)ccc12</smiles>

$48 \mathrm{R}=$ piperazin-1-yl-(p-tolyl)methane,

$$
\mathrm{IC}_{50}=70.6 \mu \mathrm{M}
$$

$49 \mathrm{R}=4-\left(1,1^{\prime}\right.$-biphenyl)-4-methylpiperazin-1-yl),

$$
\mathrm{IC}_{50}=62.3 \mu \mathrm{M}
$$

$50 \mathrm{R}=$ 4-benzylpiperazin-1-yl,

$$
\mathrm{IC}_{50}=62.2 \mu \mathrm{M}
$$<smiles>C=CC1=CCN([C@@H](O)c2ccnc3cc(Cl)ccc23)CC1</smiles>

$51 \mathrm{R}=4-(\mathrm{t}-\mathrm{Bu})$ phenyl)(piperazin-1-yl)methone,

$$
\mathrm{IC}_{50}=32.6 \mu \mathrm{M}
$$

52 L. mexicana $=10-50 \mu \mathrm{g} / \mathrm{ml}$

L. $t$. major $=10 \mu \mathrm{g} / \mathrm{ml}$

Chloroquine exhibits partial efficacy against Leishmania promastigotes and amastigotes of L. mexicana and L. donovani. Chloroquine inhibited L. donovani amastigote survival $(55 \%$ at $3 \mu \mathrm{M})$ and L. mexicana promastigote and amastigote numbers were reduced during early stages of infection, but recovered after $48 \mathrm{~h}$ $[42,43]$. Of a series of novel chloroquine-ethambutol-isoxyl tripartite hybrids only one, $53\left(\mathrm{IC}_{50}=9.90 \mu \mathrm{M}\right)$, inhibited $L$. mexicana as effectively as pentamidine $\left(\mathrm{IC}_{50}=\right.$ $13.32 \mu \mathrm{M})$ [44]. Amodiaquine analog 54 was evaluated against L. donovani, displaying an effective inhibition concentration of $2.3 \mu \mathrm{M}$ [45]. A series of 4,7chloroquinolinyl derivatives were condensed with tryptophan derivatives to identify activity against a range of Leishmania species. However, only tryptophan derivative 55 showed significant activity against L. amazoniensis, L. braziliensis, L. chagasi and L. major $\left(\mathrm{IC}_{50}=30.4,14.64,30.96\right.$ and $22.17 \mu \mathrm{M}$, respectively) although none were as active as the control, amphotericin $\mathrm{B}(0.3-1.9 \mu \mathrm{M})$ [46]. 


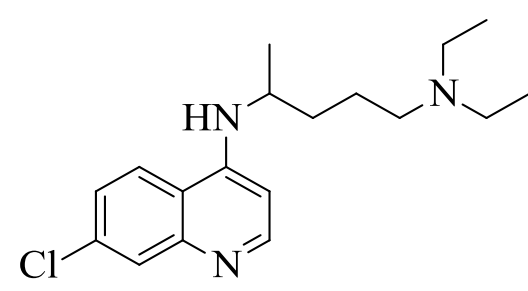

Chloroquine

amastigotes $=79 \mathrm{IP} 10 \mu \mathrm{g} / \mathrm{mL}, 48 \mathrm{hrs}$

promastigotes $=5 \mathrm{IP} 10 \mu \mathrm{g} / \mathrm{mL}, 48 \mathrm{hrs}$<smiles>[R]Nc1ccnc2cc(Cl)ccc12</smiles>

$53 \mathrm{R}=$ ethyl-3-(3-phenoxypropyl)urea,

$\mathrm{IC}_{50}=9.90 \mu \mathrm{M}$, L. mexicana

$54 \mathrm{R}=2$-(piperazin-1-yl)phenol,

$\mathrm{IC}_{50}=2.3 \mu \mathrm{M}$, L. donovani

$55 \mathrm{R}=3$-(indol-3-yl)propanoic acid,

$\mathrm{IC}_{50}=14.64 \mu \mathrm{M}$, L. braziliensis

Bisquinoline 56 displayed an $\mathrm{IC}_{50}$ of 2.0 and $2.1 \mu \mathrm{M}$ (promastigotes and amastigotes, respectively) against intracellular L. donovani. Significant reductions (compared to sodium antimony gluconate, $250 \mathrm{mg} / \mathrm{kg}$ dose, parasite burden were also identified in the parasite burden of the spleen (95\%) and liver (98.5\%) of L. donovani-infected $\mathrm{BALB} / \mathrm{c}$ mice 30 days post IP treatment [31].<smiles>Clc1ccc(O[CH]Oc2ccc(Cl)c3cccnc23)c2ncccc12</smiles>

56

L. donovani

Promastigote, $\mathrm{IC}_{50}=2.0 \mu \mathrm{M}$

Amastigote, $\mathrm{IC}_{50}=2.1 \mu \mathrm{M}$

Primaquine, a 6,8-substituted aminoquinoline used for the treatment of $P$. vivax malaria, is potent against the amastigote form of L. donovani [47]. It also exhibits potency against axenically cultured amastigotes of three Leishmania species. $L$. amazonensis and $L$. infantum amastigotes and promastigotes were equally sensitive to primaquine, while L. m. mexicana amastigotes were about two-fold more susceptible than the corresponding promastigote form [48]. Primaquine-loaded polyisohexylcyanoacrylate nanoparticles exhibited a 21-fold improvement in antileishmanial activity in vitro against $L$. donovani infected macrophages relative to primaquine alone [14]. Analogues of primaquine exhibit improved activity against a 
number of Leishmania species [49]. Analogue 57, for example, has an MEC of 10 $\mu \mathrm{g} / \mathrm{ml}$, compared to $100 \mu \mathrm{g} / \mathrm{ml}$ for the parent [30].<smiles>COc1cc(NC(C)CCCN)c2ncccc2c1</smiles>

Primaquine

L. donovani $\mathrm{IC}_{50}=19.9 \mu \mathrm{g} / \mathrm{mL}$

L. amazonensis $\mathrm{IC}_{50}=53.43 \mu \mathrm{M}$

L. inf antum $\mathrm{IC}_{50}=62.59 \mu \mathrm{M}$

L. mexicana $\mathrm{IC}_{50}=22.54 \mu \mathrm{M}$<smiles>COc1cc(NC(C)CCCNC2CN3CCC2CC3)c2ncccc2c1</smiles>

57

L. donovani $\mathrm{MEC}=10 \mu \mathrm{g} / \mathrm{ml}$

L. mexicana, $\mathrm{MEC}=10 \mu \mathrm{g} / \mathrm{ml}$

L. t. major, $\mathrm{MEC}=10 \mu \mathrm{g} / \mathrm{ml}$

\section{Trisubstituted Quinolines}

Sitamaquine (WR-6026) is the most studied example of a leishmanicidal trisubstituted quinoline with an $\mathrm{EC}_{50}$ of $5.09 \mu \mathrm{M}$ and an $\mathrm{EC}_{90}$ of $20.33 \mu \mathrm{M}$ in vitro against L. donovani [50]. It has also shown promising activity in Phase II trials for the oral treatment of VL $[51,52]$. The molecular target of this cationic molecule is not known, but it has been demonstrated to interact with mitochondrial and other lipid membranes and results in alteration of parasite morphology [53,54]. Analogues of this 4,6,8-tri-substituted quinoline bearing structural variations in the 8-[6(diethylamino)hexyl]amine] side chain have also proved active against $L$. donovani in hamsters, although none were as potent as the parent [55]. Replacing the diethylamino moiety with di- $n$-propylamino, for example, decreased the $\mathrm{G}$-index $\left(\mathrm{G}=\mathrm{SD}_{90}\right.$ for meglumine antimoniate / $\mathrm{SD}_{90}$ for test compound) from 474 to 333. Replacing this moiety with a substituted-l-piperazine or related heterocycle resulted in a greater decrease in activity in the same assay [56]. Retaining this diethylamino group, but shortening the tether from hexyl to pentyl, or lengthening it from hexyl to heptyl, also lowered the G-index (178 and 96.8 respectively). Retaining all three substituents of sitamaquine but introducing a 2-hydroxy substituent almost completely removed activity, ruling out this derivative as an active metabolite. Extending the aromatic nucleus from quinoline to acridine had a similarly deleterious effect on leishmanicidal activity [57]. 
Quinolines substituted at positions 2-, 3- and 4- are available by condensation of aniline with $\beta$-keto esters (Figure 2) [58]. A small library of these compounds demonstrated anti-leishmanial efficacy in vitro against L. chagasi promastigotes and one example (58) showed an $\mathrm{IC}_{50}$ of $3.55 \mu \mathrm{g} / \mathrm{mL}$ against amastigote-infected macrophages. This compound was about 8.3 -fold more potent than the standard pentavalent antimony $\left(\mathrm{IC}_{50}=29.55 \mu \mathrm{g} / \mathrm{mL}\right)$ in the same assay [58]. A 2,4,6substituted bisquinoline (59) compound showed activity in vitro against $L$. tarentolae with an MIC of $6.5 \mu \mathrm{g} / \mathrm{ml}$ with a low level of cytotoxicity against macrophages [59].
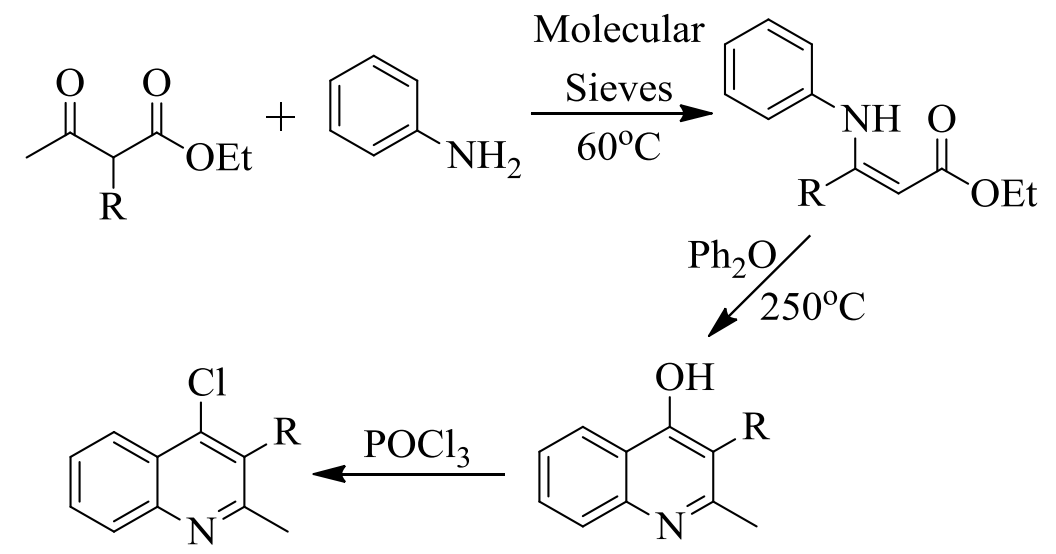

Fig. (2)<smiles>Cc1nc2ccccc2c(O)c1C/C=C/c1ccccc1</smiles>

L. Chagasi $\mathrm{IC}_{50}=3.55 \mu \mathrm{g} / \mathrm{mL}$

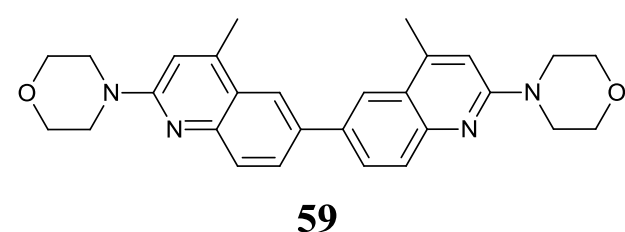

L. tarentolae $\mathrm{MEC}=6.5 \mu \mathrm{g} / \mathrm{mL}$

A trisubstituted primaquine analogue bearing an additional 2-ethyl group was the most active of a small library of 2-substituted primaquines tested against $L$. donovani in hamsters with a G-index of 10, compared with 0.96 for primaquine, 2.4 for 2methoxy primaquine and 1.6 for 2-ethenyl primaquine [60]. A 5,6,8-substituted primaquine analogue showed an MEC of 10,5 and $10 \mu \mathrm{g} / \mathrm{ml}$ respectively against Leishmania parasites L. mexicana, L. t. major and L. donovani. Compound $\mathbf{6 0}$ exhibited a 10-fold greater MEC than that of primaquine $(100 \mu \mathrm{g} / \mathrm{ml})$ [61]. 


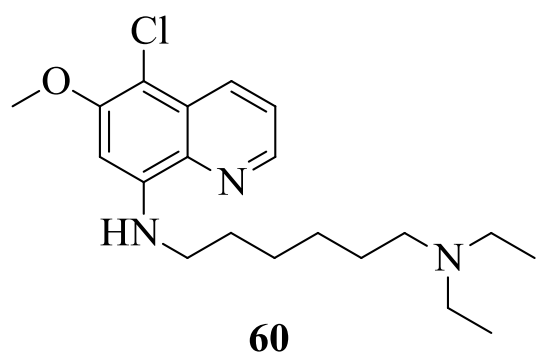

L. donovani $\mathrm{MEC}=10 \mu \mathrm{g} / \mathrm{ml}$

L. mexicana, $\mathrm{MEC}=10 \mu \mathrm{g} / \mathrm{ml}$

L. t. major, $\mathrm{MEC}=5 \mu \mathrm{g} / \mathrm{ml}$

A series of boronated 5,7,8-trisubstituted quinolines proved very effective against $L$. donovani amastigotes. The boronic ester was located at the 8-position of the quinoline moiety while the 5 and 7-positions were either halogenated, methylated or aminated. Halogenated analogues 61, 62 and 63 exhibited $\mathrm{IC}_{50}$ values of $0.052,0.15$ and 0.18 $\mu \mathrm{g} / \mathrm{ml}$, respectively. Dimethyl compound 64 and amine substituted 65 had $\mathrm{IC}_{50}$ values of 0.94 and $1.1 \mu \mathrm{g} / \mathrm{ml}$, respectively [30].<smiles>[R]B(C)Oc1c([R])cc([R])c2cccnc12</smiles>

$61 \mathrm{R}, \mathrm{R}^{\prime}=\mathrm{Cl} ; \mathrm{R}^{\prime \prime}=4-\mathrm{Cl}-\mathrm{Ph} ; \mathrm{R}^{\prime \prime}=4-\mathrm{F}-\mathrm{Ph}$

$\mathrm{IC}_{50}=0.052 \mu \mathrm{g} / \mathrm{ml}$

$62 \mathrm{R}=\mathrm{Cl}, \mathrm{R}^{\prime}=\mathrm{I} ; \mathrm{R}^{\prime \prime}=4-\mathrm{Cl}-\mathrm{Ph} ; \mathrm{R}^{\prime \prime}=4-\mathrm{Cl}-\mathrm{Ph}$

$\mathrm{IC}_{50}=0.15 \mu \mathrm{g} / \mathrm{ml}$

$63 \mathrm{R}, \mathrm{R}^{\prime}=\mathrm{Cl} ; \mathrm{R} "=3-\mathrm{F}-\mathrm{Ph} ; \mathrm{R}^{\prime \prime \prime}=\mathrm{C}_{\mathrm{N}}$
$\mathrm{IC}_{50}=0.18 \mu \mathrm{g} / \mathrm{ml}$

$64 \mathrm{R}, \mathrm{R}^{\prime}=\mathrm{CH}_{3} ; \mathrm{R}^{\prime}=4-\mathrm{Cl}-\mathrm{Ph} ; \mathrm{R}^{\prime \prime}=4-\mathrm{F}-\mathrm{Ph}$

$\mathrm{IC}_{50}=0.94 \mu \mathrm{g} / \mathrm{ml}$

$65 \mathrm{R}=\mathrm{Cl}$; R' = dimethylamine; R" = 3-Cl-4-pyridyl; R"' = vinyl

$\mathrm{IC}_{50}=1.1 \mu \mathrm{g} / \mathrm{ml}$

\section{Polysubstituted Quinolines}

The anti-leishmanial activity of tetra- and penta-substituted quinolines has not been investigated systematically. Adding additional functionality to sitamaquine generally decreases potency, although there are still a number of leishmanicidal analogues in this category and 5-methoxy sitamaquine was significantly more potent than the 
parent against L. major and L. m. amazonensis in random-bred albino mice [62]. The 2,3,4,6-substituted derivatives are readily available by the Brønstedt or Lewis acid catalysed Friedländer condensation [63,64] of 2-aminoaryl aldehydes, ketones or $\alpha$ hydroxy derivatives with carbonyl compounds (e.g. Figure 3).<smiles>[R]C(=O)c1cc([R2])ccc1N</smiles><smiles>[R4]CC([R])=O</smiles><smiles>[R]c1ccc2nc([R1])c([R4])c([R])c2c1</smiles>

Fig. (3) Friedlander synthesis

A small library of compounds, 66-70, was prepared in this way and were tested in vitro against $P$. falciparum, $L$. donovani, $L$. infantum, $T$. cruzi and T. b. rhodesiense [35]. Some of these compounds exhibited significant activity against P. falciparum and $T$. cruzi, while others displayed modest activity against $L$. donovani and $L$. infantum. One notable feature of this data is the importance of the chlorine at position 6 for leishmanicidal potency.<smiles>[R]c1nc2ccc(Cl)cc2c(-c2ccccc2)c1[R]</smiles>

$66 \mathrm{R}=\mathrm{CH}_{2} \mathrm{Cl}, \mathrm{R}^{\prime}=\mathrm{CO}_{2} \mathrm{Et} ; \mathrm{IC}_{50}=13.2 \mu \mathrm{g} / \mathrm{mL}$

$67 \mathrm{R}, \mathrm{R}^{\prime}=\mathrm{CH}_{3} ; \mathrm{IC}_{50}=12.9 \mu \mathrm{g} / \mathrm{mL}$

$68 \mathrm{R}=2$-methylpiperidine, $\mathrm{R}^{\prime}=\mathrm{CO}_{2} \mathrm{Et} ; \mathrm{IC}_{50}=$ $12.2 \mu \mathrm{g} / \mathrm{mL}$

$69 \mathrm{R}=\mathrm{CH}_{3}, \mathrm{R}^{\prime}=\mathrm{CO}_{2} \mathrm{Et} ; \mathrm{IC}_{50}=3.4 \mu \mathrm{g} / \mathrm{mL}$

$70 \mathrm{R}=\mathrm{CH}_{3}, \mathrm{R}^{\prime}=\mathrm{COMe} ; \mathrm{IC}_{50}=11.8 \mu \mathrm{g} / \mathrm{mL}$

The 2,4,6,8-substituted quinolines, compounds $\mathbf{7 1}$ and $\mathbf{7 2}$ were similarly substituted with a difference at the 2-position, which contained a phenyl or tricyclic ring. The phenyl substituent proved more toxic then the tricyclic ring with a MEC of 10 compared to $10-100 \mu \mathrm{g} / \mathrm{ml}$ in vitro against L. mexicana. Both substitutions proved more toxic then primaquine [61]. Quinolines substituted at the 2,5,7,8-position exhibited increased toxicity when substituted with a boronic ester at the 8-position. Compounds 73, 74 and $\mathbf{7 5}$ exhibited significant activity against L. donovani [30]. 
<smiles>[R]c1cc(C(O)C2CCCCN2)c2ccc(Cl)c(Cl)c2n1</smiles>

$71 \mathrm{R}=\mathrm{Ph}, \mathrm{MEC}=10 \mu \mathrm{g} / \mathrm{ml}$

$72 \mathrm{R}=\bigvee, \mathrm{MEC}=10-100 \mu \mathrm{g} / \mathrm{ml}$<smiles>[R]B([R])c1c(Cl)cc(Cl)c2ccc(C)nc12</smiles>

$73 \mathrm{R}=4-\mathrm{Cl}-\mathrm{Ph} ; \mathrm{R}^{\prime}=4-\mathrm{Cl}-\mathrm{Ph}, \mathrm{IC}_{50}=0.12 \mu \mathrm{g} / \mathrm{ml}$

$74 \mathrm{R}=3-\mathrm{Me}_{2} \mathrm{~N}-\mathrm{Ph} ; \mathrm{R}^{\prime}=$ vinyl, $\mathrm{IC}_{50}=0.16 \mu \mathrm{g} / \mathrm{ml}$

$75 \mathrm{R}=3$-pyridyl; R' = vinyl, $\mathrm{IC}_{50}=0.22 \mu \mathrm{g} / \mathrm{ml}$

The 4,5,6,8-substituted aminoquinoline, NPC1161, is an anti-malarial drug with improved activity relative to primaquine and anti-leishmanial activity against $L$. donovani [65,66]. Attaching the water soluble copolymer $\mathrm{N}$-(2hydroxypropyl)methacrylamide (HPMA) to NPC1161 reduced parasite numbers in vitro. All ManN-containing HPMA copolymer conjugates (compounds 76-79) were effective in killing all parasites at $30 \mu \mathrm{g} / \mathrm{ml}$ but were toxic to macrophages at the same dose [66]. 


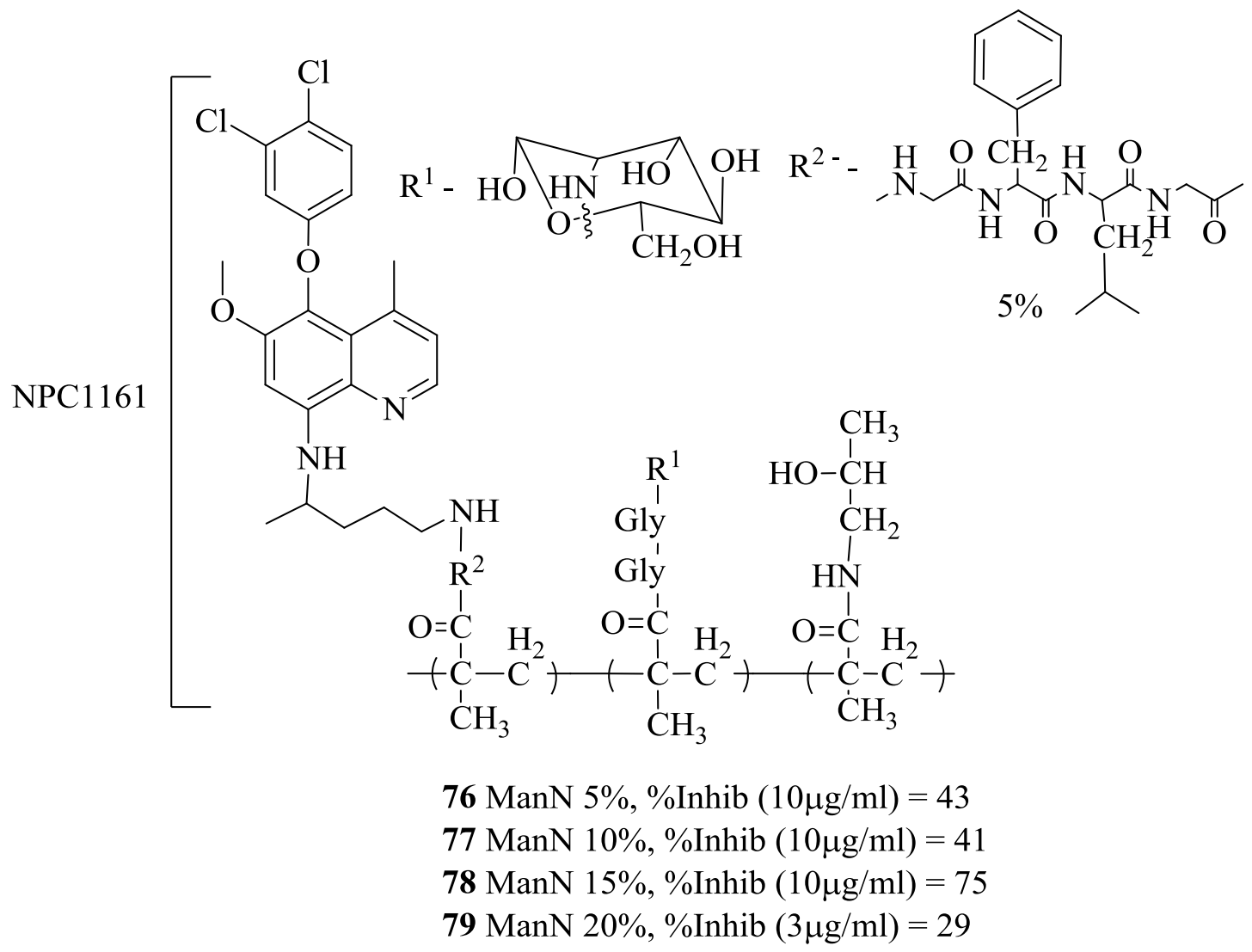

Few conclusions can be drawn from this small survey other than all the compounds examined were more active than primaquine but less active than some other simpler 8 -aminoquinolines (see above). Increasing the bulk of the 2 -substituent of primaquine is reported to increase blood-schizontocidal anti-malarial activity and reduce methemoglobin toxicity [67]. Additional 5-(3-trifluoromethylphenoxy) substitution provided the highly substituted tafenoquine (WR238605), an effective prophylactic drug [68] for use against P. falciparum and with potent in vitro anti-leishmanial activity against $L$. donovani promastigotes [49]. Compounds $\mathbf{8 0 , 8 1}$ and $\mathbf{8 2}$ have $\mathrm{IC}_{50}$ comparable to pentamidine $\left(\mathrm{IC}_{50}=3.4 \mu \mathrm{g} / \mathrm{mL}\right.$ ). $\mathrm{IC}_{90}$ values were also obtained ranging from $6.5-6.7 \mu \mathrm{g} / \mathrm{mL}$ compared with $8.0 \mu \mathrm{g} / \mathrm{mL}$ for pentamidine. However, all compounds were less potent then amphotericin $\mathrm{B}\left(\mathrm{IC}_{50}=0.17\right.$ and $\left.\mathrm{IC}_{90}=1.7 \mu \mathrm{g} / \mathrm{mL}\right)$ [49]. The 2,3,4,7,8-substituted quinoline, skimmianine, exhibited limited activity against L. braziliensis, L. donovani and L. amazonensis $\left(\mathrm{IC}_{90}=100 \mu \mathrm{g} / \mathrm{mL}\right)$ [36]. 


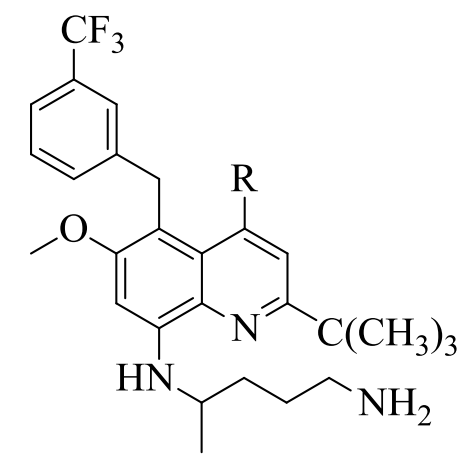

$80 \mathrm{R}=\mathrm{H} ; \mathrm{IC}_{50}=3.0 \mu \mathrm{M}$

$81 \mathrm{R}=\mathrm{CH}_{3} ; \mathrm{IC}_{50}=3.4 \mu \mathrm{M}$

$82 \mathrm{R}=\mathrm{C}_{2} \mathrm{H}_{5} ; \mathrm{IC}_{50}=2.9 \mu \mathrm{M}$

Analogues with an oxygenated substituent at the 5-position were more potent than the unsubstituted or 5-methyl compounds. This study again confirmed the importance of the C-6 substituent with the 5,6-dimethoxy and certain 6-hydroxy compounds exhibiting the highest leishmanicidal activities. Minor variations in the 8-amino sidechain had little effect in this series of compounds.

\section{Structure Activity Relationship (SAR)}

A meta-analysis of the above data allows the formulation of a qualitative SAR. This task is complicated by: (i) the different models used to assess bioactivity in vitro (promastigote and amastigote) and in vivo (mouse, canine, rat and hamster models); (ii) the different units used to quantify bioactivity (eg $\mathrm{IC}_{50}$ reported in either $\mu \mathrm{g} / \mathrm{mL}$ or $\mu \mathrm{M}, \mathrm{MEC}, \mathrm{GI}, \mathrm{G}$ Index) and (iii) the unknown and possibly different molecular targets for different classes of quinolines. The SAR presented in Figure 4 is therefore only a qualitative guide. 


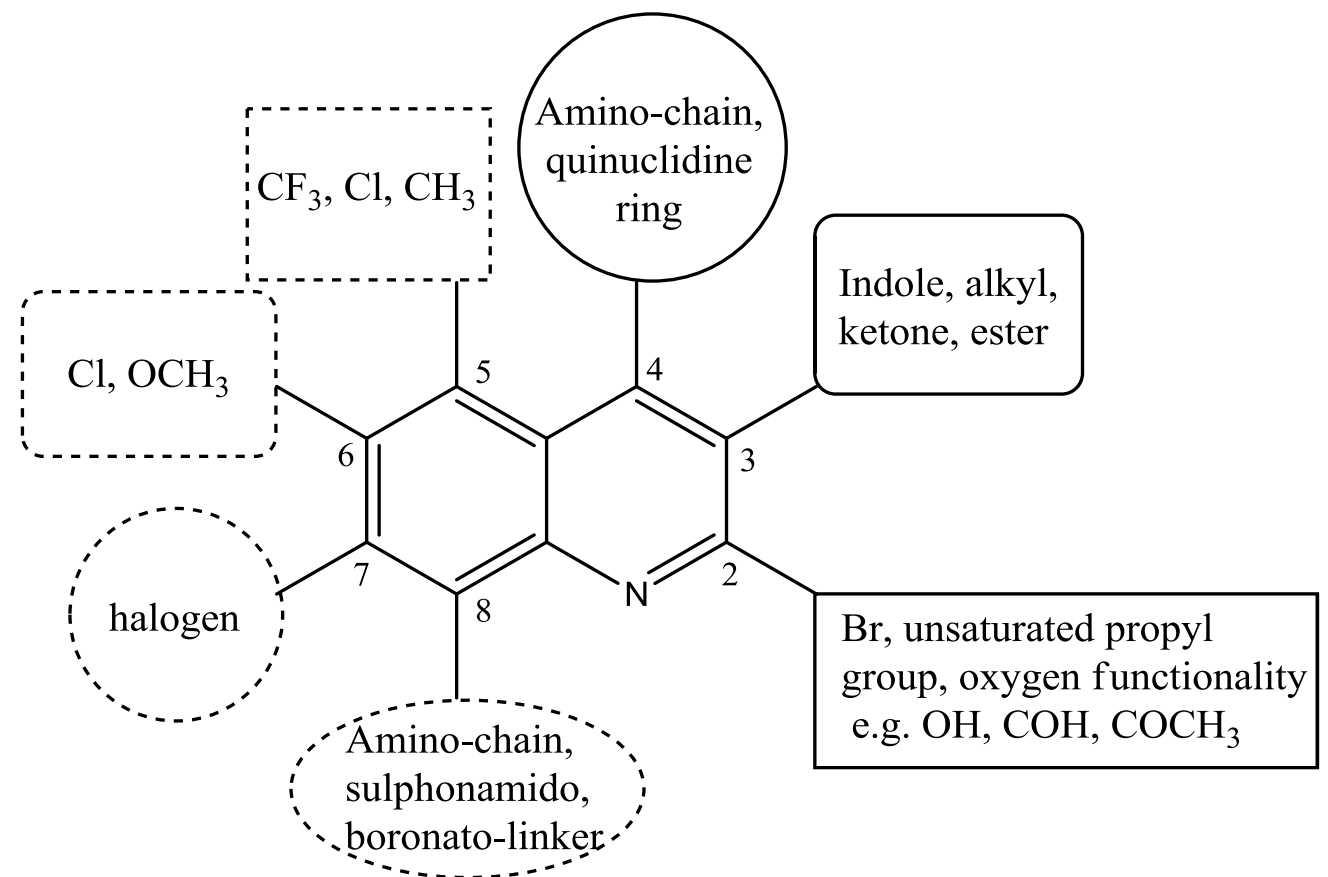

Fig. (4) General SAR of favourable substituents at each position quinoline nucleus.

This meta-analysis indicates that substitution at any position of the quinolone ring can potentially lead to improved leishmanicidal activity and improved activity is often associated with multiple substitutions. Simple mono-substituted quinolines show a variety of activities when positioned around the ring. The 2-substituted analogs, for example, exhibit greater potency if a three- to five-carbon alkyl chain is employed and activity increases if (a) C1-C2 of the chain is saturated $\left(\mathbf{1}\left(\mathrm{IC}_{50}=50 \mu \mathrm{g} / \mathrm{mL}\right), \mathbf{3}\left(\mathrm{IC}_{50}=\right.\right.$ $12 \mu \mathrm{M})$ ); (b) substitution includes (i) an allylic alcohol 5; (ii) an $\alpha, \beta$-unsaturated aldehyde 8; (iii) an $\alpha, \beta$-unsaturated ester 9; (iv) an allylic bromine 11 and 12; or (v) an alkyne $14\left(\mathrm{IC}_{50}=2 \mu \mathrm{M}\right)$. However, activity decreases for substitution of larger groups at the 2 position $\left(2-\mathrm{CH}=\mathrm{CHCH}_{2} \mathrm{CH}_{2} \mathrm{CH}_{2}, \mathrm{IC}_{50}=>30 \mu \mathrm{M}, 2-\mathrm{C}_{6} \mathrm{H}_{5}, \mathrm{IC}_{50}=\right.$ $>100 \mu \mathrm{M})$

There are relatively few studies of quinolines with single substitutents at the 3- to 7positions. Mono-substitution at the 3-position yields compounds with limited in vitro activity or compounds that are highly cytotoxic. The same is true for 5- and 6monosubstitution. The paucity of studies involving mono-substituted 3-, 5- and 6quinolines is in part due to the increased difficulty of preparing these compounds. However, multiple substituents including di-, tri- and poly-substituted, methoxy, halogen and /or methyl functionalities at the 5-, 6-, and / or 7-positions can yield 
potent quinolines such as sitamaquine and chloroquine. Conversely long chain substituents at any of these positions decreases activity dramatically. A combination of substitution at the 3-position with a 4-substituted indole, alkyl, ketone or ester can yield potent leishmanicidal compounds [16,32].

Moderate activity is seen for 2,4- and 2,6-substitution with either a 4-carboxylic acid or 6-methoxy, halogen or methyl groups combined with a 2-aryl substituent. Even more active are 4- and 8- mono-substitution involving certain alkylamines, complex ring systems, or aryl substitutions tethered via sulfonamide or boronic acid linkers. Bisquinoline derivatives (2,8- and 5,8-) exhibit potent activity when an alkyl chain (n $=1,4,5)$ is used to connect the two quinoline moieties $\left(\mathrm{IC}_{50}=2.0-3.4 \mu \mathrm{M}\right)$. Chloroquine-like (4,7-substituted) derivatives demonstrate similar patterns in activity, with alkylamine substituents $\left(\mathrm{IC}_{50}=2.3-14 \mu \mathrm{M}\right)$, piperazine $\left(\mathrm{IC}_{50}=32-70 \mu \mathrm{M}\right)$ and quinuclidine rings $\left(\mathrm{IC}_{50}=1.9-3.8 \mu \mathrm{M}\right)$. 4-Substituted quinine analogues are active at low to moderate concentrations $\left(\mathrm{IC}_{50}=10-50 \mu \mathrm{M}\right)$.

Primaquine and other 6,8-substituted derivatives exhibit modest activity, increasing 10-fold when a quinuclidine is added to the end of the 8-substituted, six-carbon chain. Extending this amino chain to eight carbons in combination with a 4-methyl $\left(\mathrm{EC}_{50}=\right.$ $5.09 \mu \mathrm{M}$ ) or 5-chloro substituent (MEC $=5-10 \mu \mathrm{g} / \mathrm{mL}$ ) is also effective. Other structural variations in the 8-amino side chain have either a detrimental or beneficial effect on activities, e.g. replacing the diethylamino $(\mathrm{G}-\mathrm{index}=474)$ with a dipropylamine increases activity $(\mathrm{G}-\mathrm{index}=333)$, as does, shortening the tether from hexyl to pentyl $(\mathrm{G}-\mathrm{index}=178$ ) or lengthening from hexyl to heptyl (G-index $=96.7)$. However, introducing a substituted piperazine or other heterocycle to an eight-carbon amino chain reduces potency.

Both, 8-sulphonamido and 8-boronato quinolines can be highly leishmanicidal compounds. The 8-arylsulphonamido substituents were less active, eg benzenesulphonamido $\left(\mathrm{IC}_{50}=0.45-13.96 \mu \mathrm{M}\right)$, pyridinesulphonamido $\left(\mathrm{IC}_{50}=2.25\right.$ $\mu \mathrm{M})$, naphthalenesulphonamido $\left(\mathrm{IC}_{50}=3.53 \mu \mathrm{M}\right)$ and thiophenesulphonamido $\left(\mathrm{IC}_{50}=\right.$ $0.53 \mu \mathrm{M})$. Increased activity was seen in all of the boronate derivatives, regardless of other quinoline ring substitution $\left(\mathrm{IC}_{50}=0.02-1.1 \mu \mathrm{M}\right)$. 


\section{Preclinical and Clinical Development.}

Although aspects of the mechanism of action, metabolism and toxicity of selected quinolines have been described, in general these areas of preclinical development are not well understood. This is partly due to the patchy approach to these studies. A quinoline, active against another target, and for which drug approval has been obtained, is then tested in leishmaniasis studies, but the mechanism of action is not generally pursued - it is either effective or it is not. Imiquimod, for example, has been approved for external warts in adults [69] and is a successful leishmanicide, but its mechanism of action is not fully understood. Saquinavir, an HIV-protease inhibitor has also proved ineffective against VL [70]. Progression of quinolines through preclinical studies is inconsistent with most interest on chloroquine, Imiquimod, mefloquine, primaquine, sitamaquine and a few, selected substituted quinolines. A précis of the current knowledge in this area is presented below.

It is important to note that preclinical studies have involved a variety of animal models. In mice tests, for example, mice (such as random-bred albino mice (TFW line) [71] or Balb/c mice [25]) are infected subcutaneously on their back and median lesions scores determined. Other animals (mongrel and parasite-free beagle dogs [72], opossums [73] and rats [74]) have also been used for screening with quite different responses between species. The most widely used and reliable model is the $L$. donovani-hamster model. In this system, the suppressive effect of a compound on the parasite densities in the hamster's liver is compared to that of a reference compound, usually meglumine antimoniate.

The anti-leishmanial efficacies of medicinal plant extracts [15] 1, 2, 3, 4, 2phenylquinoline and 2-(3,4-methylenedioxyphenyl ethyl) quinoline, were evaluated in BALB/c mice infected with L. amazonensis or L. venezuelensis $[15,16,36,75]$ or $L$. donovani [76]. Subcutaneous treatment of L. donovani-infected BALB/c mice infected with 2 for 10 days at $0-54 \mathrm{mmol} / \mathrm{kg}$ per day resulted in $86-6 \%$ parasite suppression in the liver [76]. Oral administration of $0-54 \mathrm{mmol} / \mathrm{kg}$ of $2-\mathrm{n}$ propylquinoline once daily for 5 or 10 days to $L$. donovani-infected mice suppressed parasite burdens in the liver by $87-8$ and $99-9 \%$, respectively [76]. In a study with $L$. amazonensis or L. venezuelensis infected BALB/c mice, three-carbon chain quinolines (1 and 2) were more potent than $N$-methylglucamine antimonate against $L$. 
amazonensis, and other 2-substituted quinoline alkaloids such as [2-(3,4 methylenedioxy phenylethyl) quinoline, 2-(3,4-dimethoxyphenylethyl)quinoline, and 3, were as effective as the reference drug [15]. In another study, also with BALB/c mice infected with L. amazonensis or L. venezuelensis, five injections of chimanine B at intervals of 4 days reduced the lesion weight by $74 \%$ and the parasite loads in the lesion by $90 \%$ compared with the values for the group of untreated mice [16]. Other 2-substituted quinolines, 1 administered by the oral and intralesional routes, 2phenylquinoline administered by the oral route, $\mathbf{4}$ administered by intralesional injection, and two total alkaloidal extracts of $G$. longiflora administered by the oral route, had intermediate effects [16]. The variable leishmanicidal activities could not be explained because the modes of action of these compounds are unknown. However, the active 2-substituted quinolines, $\mathbf{1}$ or $\mathbf{3}$, were reported to have good absorption and to be metabolized at low levels, resulting in the choice of $\mathbf{3}$ as the lead compound [16].

Subsequent to the above studies on 2-substituted quinolines, the development of a high-performance liquid chromatographic method for the specific determination of $\mathbf{1}$, in plasma and liver homogenates of mice was reported [77]. This method was an aid to preclinical studies and was used to determine the pharmacokinetic profile of $\mathbf{1}$ following oral administration to mice [77]. More recently, the in vivo efficacy of 2substituted quinolines on L. amazonensis CL in BALB/c mice and on L. infantum and L. donovani visceral infection in BALB/c mice established differential efficacy [17]. 2-Substituted quinolines (where the 2 substituent was $-\mathrm{C} \equiv \mathrm{CH},-\mathrm{CH}=\mathrm{CHC}(\mathrm{O}) \mathrm{H}$, $\mathrm{CH}=\mathrm{CHCH}_{2} \mathrm{OH}$, or $-\mathrm{CH}=\mathrm{CHCH}_{2} \mathrm{OCH}_{3}$ ) were significantly more effective than meglumine antimoniate in reducing the parasite burden in both the liver and spleen. Quinoline 1 and 5 at $12.5 \mathrm{mg} / \mathrm{kg}$ significantly reduced the parasite burdens in the liver by $\sim 60-70 \%$. Quinoline 5 was the most promising compound against both CL and VL. These compounds displayed double anti-leishmanial and anti-viral activities, which suggested they could be potentially used as a treatment for co-infection of Leishmania-HIV [17].

Preclinical studies have included a range of di-, tri- and tetra-substituted quinoline derivatives that could be considered to be derivatives of the frontline, potential antileishmanial lead compounds primaquine and sitamaquine. However, there are a few 
notable exceptions such as an indolylquinoline [33], Imiquimod [78], chloroquine [79] and mefloquine [62], which will be discussed first. An indolylquinoline derivative (2-(2''-dichloroacetamidobenzyl)-3-(3'-indolylquinoline)) has been reported to reduce the parasite burdens in the spleen and liver by $>93 \%$ in $L$. donovani-infected hamsters. Combination therapy of the indolylquinoline derivative with sodium antimony gluconate cured established VL in hamsters, with no residual living parasites in the livers and spleens of infected animals [33]. Chloroquine did not inhibit the multiplication of $L$. donovani in hamster livers when administered at 100 $\mathrm{mg} / \mathrm{kg} /$ day for 12 days [79], or L. major in TFW mice when administered at 90 $\mathrm{mg} / \mathrm{kg} /$ day for 5 days [62]. These results stand in contrast to the activity observed in vitro (Section 3). In the latter study, mefloquine displayed moderate activity levels against L. major in TFW mice when administered at $70 \mathrm{mg} / \mathrm{kg} /$ day for 5 days [62]. However, in a non-blinded, therapeutic trial conducted in Columbia, 1.25-1.5 grams of mefloquine given as a single oral dose or a dose of $250 \mathrm{mg}$ a day for 5-6 days was not efficacious in the treatment of New world CL[80], whereas a trial in Ecuador gave a cure to $68 \%$ of patients (11 patients) in four weeks or less $[81,82]$. Issues such as patient compliance, early vomiting, superinfection of lesions, a potential difference in the bioavailability of the drug due to methods of manufacture, and classification of lesions at a point in time (lesion might initially enlarge before healing) complicate the direct comparison of the two mefloquine trials.

\section{Imiquimod}

Topical treatment with 5\% Imiquimod cream (compared with a placebo cream) of $L$. major-infected BALB/c mice significantly reduced the severity of the lesions on the footpads of the mice, with less swelling due to infection, fewer parasites, and inhibition of surface ulceration. However, as Imiquimod is unlikely to penetrate as far as the inner regions of the foot, infection was expected to spread further if treatment were stopped in this animal model [78]. Recently, clinical trials using Imiquimod, topical treatment three times a week with Imiquimod cream $(5 \%)$ on patients (from Damascus) led to regression of lesions of CL after 4 weeks. However after this time clinical deterioration occurred. It was concluded that topical application of Imiquimod alone was ineffective in treating Old World CL [83]. A further two Imiquimod trials, gave more promising outcomes. In the first trial, topical treatment of the drug (over 20 days) in combination with ongoing antimonial therapy led to $57 \%$ of lesions and $50 \%$ 
of patients (12 patients in total) being clinically 'cured' at day 20, with $90 \%$ patients being cured at 6 months $[69,84]$. In the second trial (which was a double-blind randomized trial), treatment of forty patients (in Peru) with clinical resistance to antimony, received megluamine antimoniate $(20 \mathrm{mg} / \mathrm{kg} / \mathrm{day}$ intramuscularly (IM) or intravenously (IV)) and were randomized to receive topical Imiquimod (5\%). The Imiquimod group achieved a $72 \%$ cure at 3 months versus $35 \%$ of the vehicle cream group (control group). Residual scarring was less prominent when Imiquimod was used [85].

\section{Primaquine}

Interest in use of primaquine as an anti-leishmanical agent traces back almost forty years. Altough quite toxic, primaquine, administered in conjunction with either quinine or chloroquine, is used to treat the $P$. vivax and $P$. ovale malaria [86], and is used if no other alternatives are effective [87]. In an initial clinical trial (Ethiopia, 1970), primaquine displayed minor efficacy (1 patient of 7 patients was cured) against diffuse CL [88]. However, an observation that the 2-benzyloxy derivative of primaquine was less toxic [89,90], suggested the possibility of a more effective and less toxic agent may be found and stimulated work on derivatives of primaquine. This included work on the 2-methoxy or 2-ethyl derivatives of primaquine, with activity against $L$. donovani in hamsters [60]; a 8-piperazin-1'-ylhexyl amino derivative (83) (moxipraquine) which was effective against $L$. major, L. m. mexicana and $L$. brasiliensis but displayed significant foetal toxicity [91]; 4-methyl-5-fluoro derivatives (84) of primaquine, which displayed a ten-fold increase against $L$. donovani in golden hamsters, as compared to primaquine [92]; 4-amino-2methoxyacridine derivatives $\mathbf{( 8 5 - 8 7 )}$ of primaquine, which had poor activity against $L$. donovani in hamsters [57]; a survey of 8-aminoquinolines including several 4methylquinolines (also known as lepidines, e.g. 88-90), with low activity against $L$. major or L. amazonesis in random bred albino mice [62]; and 8-amino-6-methoxy lepidine derivatives (e.g. 91-93), active against $L$. donovani in hamsters [93]. It was demonstrated in the latter study that the presence of a 4-methyl group on primaquine (94) analogues produced a marked enhancement in anti-leishmanial effectiveness, and that a 6-methoxy lepidine (95) bearing a 8-(6-diethylaminohexyl amino) group was also effective [93]. The quinoline derivative that possessed a 4-methyl-6-methoxy-8(6-diethylaminohexyl amino) group was to become known as sitamaquine [93]. 


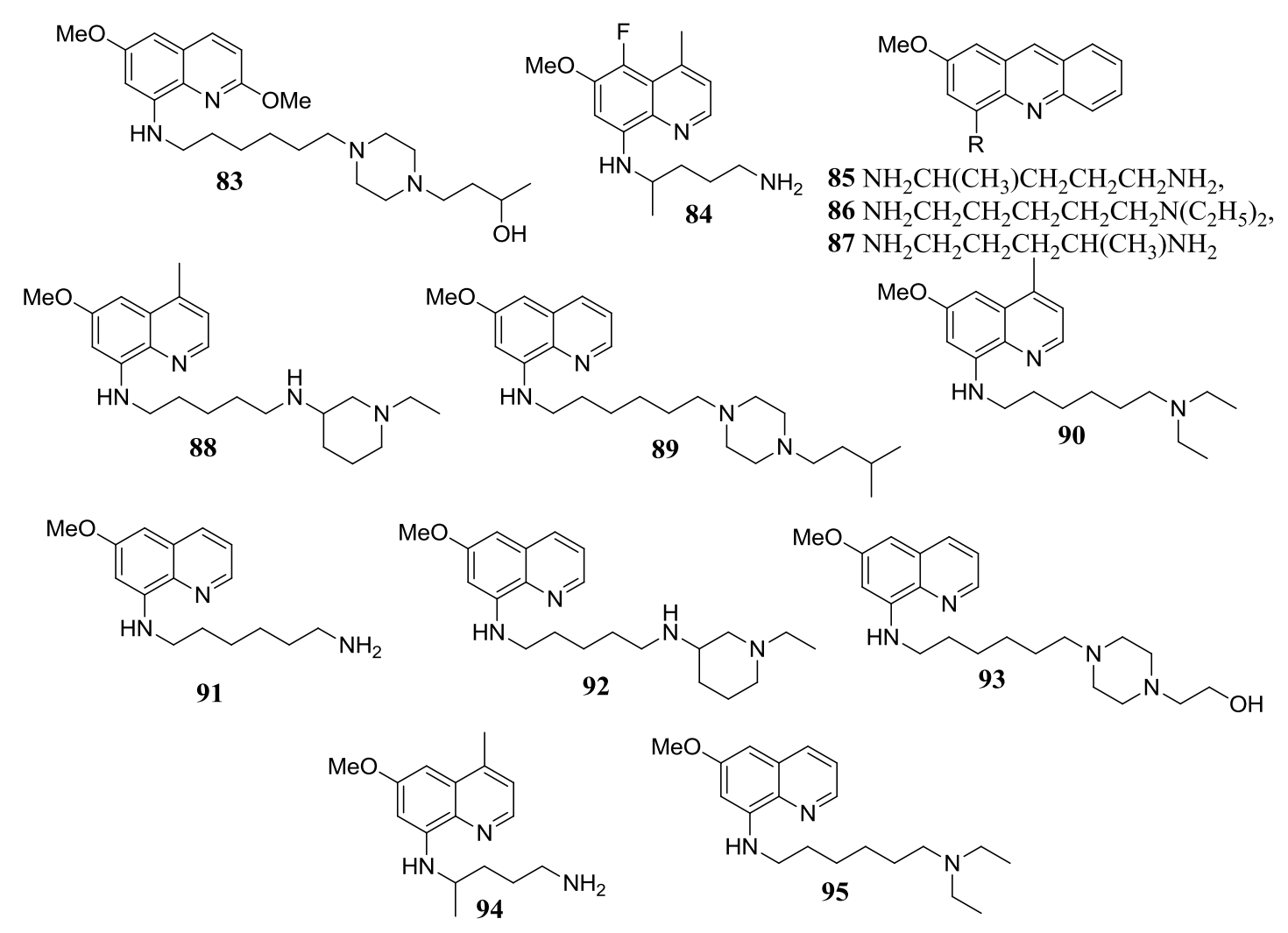

Studies during the last 20 years into the improved delivery of primaquine have included use of liposome carriers [94,95], peptide grafted liposomes [96], a selfgelling primaquine-gum arabic conjugate [97], nanoparticles (typically 150 to $200 \mathrm{~nm}$ in size) [96,98-100] and biodegradable microspheres (1-20 $\mu \mathrm{M}$ in size) [101]. Aspects such as polymer-drug interactions, in vitro drug release and physiochemical stability and toxicity were considered in some of these studies $[97,99,101,102]$. These delivery systems were aimed at increased effectiveness, prolonged duration of action and / or reduced toxicity of the drug. The effectiveness of the primaquine-loaded nanoparticles was 3.3 times as high as the free drug [96], whereas microspheres were 100 times more efficient than the free drug, primaquine [101].

\section{Sitamaquine}

Sitamaquine (formerly WR-6026) is an orally active 8-aminoquinoline in development for treatment of VL and has been reviewed elsewhere [103]. Early studies identified sitamaquine as more active against L. major in vivo (random-bred albino mice, TFW line) than in tissue culture [62]; active in mice infected with $L$. donovani [104] and active in mongrel and parasite-free beagle dogs infected with $L$. 
d. khartoum [69]. Sitamaquine also displayed parasite suppression in the liver and spleen of opposums infected with L. donovani [85]. These results stimulated the synthesis and evaluation of a variety of 8 -amino side chain analogues against $L$. donovani in hamsters as well as other ring substituted quinoline analogues [55,105107]. Although several analogues had meglumine antimoniate indexes in excess of 300 [55], none was superior to sitamaquine. Topical formulations of sitamaquine (anhydrous gel emulsions) did not affect lesion progression or reduce parasite burden in BALB/c mice infected with L. major [109]. Encapsulated within liposomes prior to injection into hamsters was 700 to 1800 times more effective than the control antimonial drug (meglumine antimoniate). In addition, the duration of action was prolonged, and the drug toxicity decreased [110,111]. Similarly, N-(2hydroxypropyl)methacrylamide (HPMA) co-polymer - NPC1161 sitamaquine conjugate containing lysosomally degradable side chains, was shown to be more effective than the free drug in BALB/c mice infected with $L$. donovani, indicating the potential for targeted delivery [112].

While the mode of action of 8 -aminoquinolines and sitamaquine is not yet understood. It has been suggested that 8 -aminoquinolines interfere with mitochondrial respiration, possibly through interactions with ubiquinones [62]. The major metabolites of sitamaquine have been identified as the desmethyl and $4-\mathrm{CH}_{2} \mathrm{OH}$ derivatives in rats and hamsters [113], with 5-hydroxylation and side chain oxidation being important steps in the metabolic pathway [114]. The 4- $\mathrm{CH}_{2} \mathrm{OH}$ derivative is the major urinary metabolite in humans, however only $14 \%$ of the drug could be accounted for [114]. Analysis of the physiochemical interactions of sitamaquine were studied using phospholipids to represent a parasite membrane, the first barrier to be crossed by a drug. This study indicated that initial electrostatic interaction between positively charged sitamaquine and the negative headgroups of the anionic phospholipids was required for subsequent hydrophobic interactions between the aromatic ring of sitamaquine and the phospholipid alkyl chains which led to drug insertion into the monolayer [53].

A major concern with the clinical development of 8 -aminoquinolines, such as primaquine, is that such compounds can cause oxidant-induced hemolytic anemia with methemoglobinemia (a higher than normal level of methemoglobin, metHb, in 
the blood, resulting in tissue hypoxia). A subchronic study of sitamaquine in SpragueDawley rats (receiving up to $12 \mathrm{mg} / \mathrm{kg} / \mathrm{day}$ for 13 weeks) and Beagle dogs (receiving up to $3 \mathrm{mg} / \mathrm{kg} / \mathrm{day}$ for 13 weeks) indicated that only the highest doses caused hemolytic anemia and methemoglobinemia, along with assocated hepatoxicity. The toxic effects of sitamaquine were essentially resolved by the end of the recovery period in both species [74].

Sitamaquine has been in development for 15 years and has attracted interest in India and the Drugs for Neglected Diseases Group [115-117]. It was initially developed at the Walter Reed Army Institute of Research for treatment of leishmaniasis, with GlaxoSmithKline helping with the final development and FDA submission. After a pilot study in India [118], several small phase I/II clinical trials have been run. In Brazil $67 \%$ of patients (total patients $=95)$ treated with sitamaquine $(2 \mathrm{mg} / \mathrm{kg} / \mathrm{day}$ for 28 days) were cured of L. Chagasi[119]. In Kenya, 83\% of patients (total patients = 46) were cured of VL when treated with sitamaquine $(1.7 \mathrm{mg} / \mathrm{kg} / \mathrm{day}$ for 28 days) [51]. Similarly, in India $81 \%$ of patients (total patients $=31$ ) were cured of VL when treated with sitamaquine $(1.5 \mathrm{mg} / \mathrm{kg} /$ day for 28 days). Sitamaquine was generally well tolerated by the patients in these studies, however side effects such as renal adverse events [101] were observed in a few subjects and this appeared to be treatmentrelated. Interpretation of these data is complicated because VL itself is associated with renal impairment. Sitamaquine has also been used in cross disease studies where a single report of the drug used in a HIV-positive patient with VL indicated that the patient responded to the use of sitamaquine [120].

\section{Concluding Remarks}

A new treatment for VL is urgently needed. Current medicines suffer from impractical treatment regimens, emerging drug resistance, or are simply unaffordable. Quinolines are a promising class of candidates in this respect and certain examples are potentially effective and affordable chemotherapies for this devastating disease. Unfortunately, the molecular targets of these drugs are not known and rational drug design is further hampered by the wide variety of disease models and methods of reporting leishmanicidal efficacy. In particular, a standardized in vivo model would 
allow quantitative comparisons of drug potency. Nevertheless, the above metastudy provides qualitatively trends useful for further investigation.

\section{Conflict of Interest and Patient Consent}

DJY is grateful to the Australian Academy of Science for financial assistance to travel to the laboratory of Professor Margaret Phillips, University of Texas, Southwestern Medical Center.

\section{Acknowledgements}

The authors wish to thank Professor Phillips for helpful discussion, Griffith University and the Universiti Brunei Darussalam.

\section{Abbreviations}

$\mathrm{CL}=$ cutaneous leishmaniasis

$\mathrm{MCL}=$ mucocutaneous leishmaniasis

$\mathrm{VL}=$ visceral leishmaniasis

HAART $=$ highly active anti-retrovial therapy

$\mathrm{IC}_{50}=$ Concentration of the drug to achieve a $50 \%$ of inhibition of disease

$\mathrm{IC}_{90}=$ Concentration of the drug to achieve a $90 \%$ of inhibition of disease

$\mathrm{EC}_{50}=$ Concentration of the drug that produces $50 \%$ of the maximum possible result

$\mathrm{EC}_{90}=$ Concentration of the drug that produces $90 \%$ of the maximum possible result

MIC $=$ Minimum Inhibitory Concentration

$\mathrm{MEC}=$ minimum effective concentration

$\mathrm{G}$-index $=\mathrm{G}=\mathrm{SD}_{90}$ for meglumine antimoniate $/ \mathrm{SD}_{90}$ for test compound

HPMA $=N$-(2-hydroxypropyl)methacrylamide

GI $=$ growth inhibition

$\mathrm{IP}=$ Intraperoteneal $(10 \mu \mathrm{g} / \mathrm{ml}, 48 \mathrm{hrs})$ 


\section{References}

[1] Peters, N.C.; Egen, J.G.; Secundino, N.; Debrabant, A.; Kimblin, N.; Kamhawi, S.; Lawyer, P.; Fay, M.P.; Germain, R.N.; Sacks, D., In vivo imaging reveals an essential role for neutrophils in leishmaniasis transmitted by sand flies. Science, 2008, 321, 970-74.

[2] van Zandbergen, G.; Bollinger, A.; Wenzel, A.; Kamhawi, S.; Voll, R.; Klinger, M.; Müller, A.; Hölscher, C.; Herrmann, M.; Sacks, D.; Solbach, W.; Laskay, T., Leishmania disease development depends on the presence of apoptotic promastigotes in the virulent inoculum. Proc. Nat. Acad. Sci., 2006, 103, 13837-42.

[3] Liese, J.; Schleicher, U.; Bogdan, C., The innate immune response against Leishmania parasites. Immunobiology, 2008, 213, 377-87.

[4] Cardenas, R.; Sandoval, C.M.; Rodriguez-Morales, A.J.; Franco-Paredes, C., IMPACT OF CLIMATE VARIABILITY IN THE OCCURRENCE OF LEISHMANIASIS IN NORTHEASTERN COLOMBIA. Am. J. Trop. Med. Hyg., 2006, 75, 273-77.

[5] Alvar, J.; Aparicio, P.; Aseffa, A.; Den Boer, M.; Canavate, C.; Dedet, J.-P.; Gradoni, L.; Ter Horst, R.; Lopez-Velez, R.; Moreno, J., The Relationship between leishmaniasis and AIDS: the Second 10 Years. Clin. Microbiol. Rev., 2008, 21, 33459.

[6] Ashutosh; Sundar, S.; Goyal, N., Molecular mechanisms of antimony resistance in Leishmania. J. Med. Microbiol., 2007, 56, 143-53.

[7] Demicheli, C.; Frezard, F., Pentavalent Antimonials: From Chemistry to the Design of New Drugs. Drug Des. Rev., 2005, 2, 243-49.

[8] Amato, V.S.; Tuon, F.F.; Bacha, H.A.; Neto, V.A.; Nicodemo, A.C., Mucosal leishmaniasis: Current scenario and prospects for treatment. Acta Trop., 2008, 105, 19.

[9] Golenser, J.; Domb, A., New formulations and derivatives of Amphotericin B for treatment of Leishamaniasis. Mini-Rev. Med. Chem., 2006, 6.

[10] Chappuis, F.; Sundar, S.; Hailu, A.; Ghalib, H.; Rijal, S.; Peeling, R.W.; Alvar, J.; Boelaert, M., Visceral leishmaniasis: what are the needs for diagnosis, treatment and control? Nat. Rev. Micro., 2008.

[11] Berman, J.D., Development of Miltefosine for the Leishmaniases. Mini-Rev. Med. Chem., 2006, 6, 145-51.

[12] Salem, M.M.; Werbovetz, K.A., Natural products from plants as drug candidates and lead compounds against leishmaniasis and trypanosomiasis. Curr. Med. Chem., 2006, 13, 2571-98.

[13] Zufferey, R.; Mamoun, C.B., Choline transport in Leishmania major promastigotes and its inhibition by choline and phosphocholine analogs. Mol. Biochem. Parasitol., 2002, 125, 127-34.

[14] Tekwani, B.L.; Walker, L.A., 8-Aminoquinolines: future role as antiprotozoal drugs. Curr. Opin. Infect. Dis., 2006, 19, 623-31.

[15] Fournet, A.; Barrios, A.A.; Munoz, V.; Hocquemiller, R.; Cave, A.; Bruneton, J., 2-substituted quinoline alkaloids as potential antileishmanial drugs. Antimicrob. Agents Chemother., 1993, 37, 859-63.

[16] Fournet, A.; Ferreira, M.E.; Rojas De Arias, A.; Torres De Ortiz, S.; Fuentes, S.; Nakayama, H.; Schinini, A.; Hocquemiller, R., In vivo efficacy of oral and intralesional administration of 2- substituted quinolines in experimental treatment of new world cutaneous leishmaniasis caused by Leishmania amazonensis. Antimicrob. Agents Chemother., 1996, 40, 2447-51. 
[17] Nakayama, H.; Loiseau, P.M.; Bories, C.; Torres de Ortiz, S.; Schinini, A.; Serna, E.; Rojas de Arias, A.; Fakhfakh, M.A.; Franck, X.; Figadere, B.; Hocquemiller, R.; Fournet, A., Efficacy of Orally Administered 2-Substituted Quinolines in Experimental Murine Cutaneous and Visceral Leishmaniases. Antimicrob. Agents Chemother., 2005, 49, 4950-56.

[18] Croft, S.L.; Coombs, G.H., Leishmaniasis- current chemotherapy and recent advances in the search for novel drugs. Trends Parasitol., 2003, 19, 502-08.

[19] Berman, J., Clinical status of agents being developed for leishmaniasis. Expert Opin. Investig. Drugs, 2005, 14, 1337-46.

[20] Fournet, A.; Angelo Barrios, A.; Munoz, V.; Hocquemiller, R.; Roblot, F.; Bruneton, J.; Richomme, P.; Gantier, J.C. Preperation of 2-substituted quinolines for treating leishmaniasis. April 15, 1993.

[21] Desrivot, J.; Herrenknecht, C.; Ponchel, G.; Garbi, N.; Prina, E.; Fournet, A.; Bories, C.; Figadere, B.; Hocquemiller, R.; Loiseau, P.M., Antileishmanial 2substituted quinolines: In vitro behaviour towards biological components. Biomed. Pharmacother., 2007, 61, 441-50.

[22] Belliard, A.M.; Leroy, C.; Banide, H.; Farinotti, R.; Lacour, B., Decrease of intestinal P-glycoprotein activity by $2 \mathrm{n}$-propylquinoline, a new oral treatment for visceral leishmaniasis. Exp. Parasitol., 2003, 103, 51-56.

[23] Fakhfakh, M.A.; Fournet, A.; Prina, E.; Mouscadet, J.-F.; Franck, X.; Hocquemiller, R.; Figadere, B., Synthesis and biological evaluation of substituted quinolines: potential treatment of protozoal and retroviral co-infections. Bioorg. Med. Chem., 2003, 11, 5013-23.

[24] Vieira, N.C.; Herrenknecht, C.; Vacus, J.; Fournet, A.; Bories, C.; Figadère, B.; Espindola, L.S.; Loiseau, P.M., Selection of the most promising 2-substituted quinoline as antileishmanial candidate for clinical trials. Biomed. Pharmacother., 2008, 62, 684-89.

[25] Nakayama, H.; Desrivot, J.; Bories, C.; Franck, X.; Figadere, B.; Hocquemiller, R.; Fournet, A.; Loiseau, P.M., In vitro and in vivo antileishmanial efficacy of a new nitrilquinoline against Leishmania donovani. Biomed. Pharmacother., 2007, 61, 186-88.

[26] Savoia, D.; Allice, T.; Tovo, P.-A., Antileishmanial activity of HIV protease inhibitors. Int. J. Antimicrob. Agents, 2005, 26, 92-94.

[27] Cammerer, S.B.; Jimenez, C.; Jones, S.; Gros, L.; Lorente, S.O.; Rodrigues, C.; Rodrigues, J.C.F.; Caldera, A.; Perez, L.M.R.; da Souza, W.; Kaiser, M.; Brun, R.; Urbina, J.A.; Pacanowska, D.G.; Gilbert, I.H., Antimicrob. Agents Chemother. Acta Trop., 2007, 51, 4049-61.

[28] Perez-Victoria, J.M.; Cortes-Selva, F.; Parodi-Talice, A.; Bavchvarov, B.I.; Perez-Victoria, F.J.; Munoz-Martinez, F.; Maitrejean, M.; Costi, M.P.; Barron, D.; Di Pietro, A.; Castanys, S.; Gamarro, F., Combination of suboptimal doses of inhibitors targeting different domains of LtrMDR1 efficiently overcomes resistance of Leishmania spp. to miltefosine by inhibiting drug efflux. Antimicrob. Agents Chemother., 2006, 50, 3102-10.

[29] da Silva, L.E.; Joussef, A.C.; Pacheco, L.K.; da Silva, D.G.; Steindel, M.; Rebelo, R.A., Synthesis and in vitro evaluation of leishmanicidal and trypanocidal activities of N-quinolin-8-yl-arylsulfonamides. Bioorg. Med. Chem., 2007, 15, 755360 .

[30] Bellinger-Kawahara, C.; Maples, K.R. Anti-parasitic uses of quinolin-8-yl borinates and boryl picolinates. 2005. 
[31] Palit, P.; Paira, P.; Hazra, A.; Banerjee, S.; Gupta, A.D.; Dastidar, S.G.; Mondal, N.B., Phase transfer catalyzed synthesis of bis-quinolines: Antileishmanial activity in experimental visceral leishmaniasis and in vitro antibacterial evaluation. European Journal of Medicinal Chemistry, 2009, 44, 845-53.

[32] Chakrabarti, G.; Basu, A.; Manna, P.P.; Mahato, S.B.; Mandal, N.B.; Bandyopadhyay, S., Indolylquinoline derivatives are cytotoxic to Leishmania donovani promastigotes and amastigotes in vitro and are effective in treating murine visceral leishmaniasis. J. Antimicrob. Chemother., 1999, 43, 359-66.

[33] Pal, C.; Raha, M.; Basu, A.; Roy, K.C.; Gupta, A.; Ghosh, M.; Sahu, N.P.; Banerjee, S.; Mandal, N.B.; Bandyopadhyay, S., Combination therapy with indolylquinoline derivative and sodium antimony gluconate cures established visceral leishmaniasis in hamsters. Antimicrob. Agents Chemother., 2002, 46, 259-61.

[34] Ray, S.; Sadhukhan, P.K.; Mandal, N.B.; Mahato, S.B.; Majumder, H.K., Dual inhibition of DNA topoisomerases of Leishmania donovani by novel indolyl quinolines. Biochem. Biophys. Res. Commun., 1997, 230, 171-75.

[35] Muscia, G.C.; Bollini, M.; Carnevale, J.P.; Bruno, A.M.; Asis, S.E., Microwave-assisted Friedlaender synthesis of quinolines derivatives as potential antiparasitic agents. Tetrahedron Lett., 2006, 47, 8811-15.

[36] Fournet, A.; Barrios, A.A.; Munoz, V.; Hocquemiller, R.; Roblot, F.; Cave, A.; Richomme, P.; Bruneton, J., Antiprotozoal activity of quinoline alkaloids isolated from Galipea longiflora, a Bolivian plant used as a treatment for cutaneous leishmaniasis. Phytotherapy Research, 1994, 8, 174-8.

[37] Muscia, G.C.; Carnevale, J.P.; Bollini, M.; Asis, S.E., Microwave-assisted Dobner Synthesis of 2-Phenylquinoline-4-carboxylic acids and their antiparasitic activities. J. Heterocyclic Chem., 2008, 45, 611-14.

[38] Sahu, N.P.; Pal, C.; Mandal, N.B.; Banerjee, S.; Raha, M.; Kundu, A.P.; Basu, A.; Ghosh, M.; Roy, K.C.; Bandyopadhyay, S., Synthesis of a novel quinoline derivative, 2-(2-methylquinolin-4-ylamino)-N-phenylacetamide--a potential antileishmanial agent. Bioorg. Med. Chem., 2002, 10, 1687-93.

[39] Kouznetsov, V.V.; Vargas Mendez, L.Y.; Milena Leal, S.; Mora Cruz, U.; Andres Coronado, C.; Melendez Gomez, C.M.; Romero Bohorquez, A.R.; Escobar Rivero, P., Target-Oriented Synthesis of Antiparasitic 2-Hetaryl Substituted Quinolines Based on Imino Diels-Alder Reactions. Lett. Drug Des. Discovery, 2007, 4, 293-96.

[40] Faruk Khan, M.O.; Levi, M.S.; Tekwani, B.L.; Wilson, N.H.; Borne, R.F., Synthesis of isoquinuclidine analogs of chloroquine: Antimalarial and antileishmanial activity. Bioorg. Med. Chem., 2007, 15, 3919-25.

[41] Lackovic, K.; Parisot, J.P.; Sleebs, N.; Baell, J.B.; Debien, L.; Watson, K.G.; Curtis, J.M.; Handman, E.; Street, I.P.; Kedzierski, L., Inhibitors of Leishmania GDPMannose Pyrophosphorylase Identified by High-Throughput Screening of SmallMolecule Chemical Library. Antimicrob. Agents Chemother., 2010, 54, 1712-19.

[42] Chaudhuri, G.; Mukhopadhyay, A.; Basu, S.K., Selective delivery of drugs to macrophages through a highly specific receptor. An efficient chemotherapeutic approach against leishmaniasis. Biochem. Pharmacol., 1989, 38, 2995-3002.

[43] Alexander, J., Leishmania mexicana: inhibition and stimulation of phagosome-lysosome fusion in infected macrophages. Exp. Parasitol., 1981, 52, 261 70 .

[44] Nava-Zuazo, C.; Estrada-Soto, S.; Guerrero-Álvarez, J.; León-Rivera, I.; Molina-Salinas, G.M.; Said-Fernández, S.; Chan-Bacab, M.J.; Cedillo-Rivera, R.; Moo-Puc, R.; Mirón-López, G.; Navarrete-Vazquez, G., Design, synthesis, and in 
vitro antiprotozoal, antimycobacterial activities of $\mathrm{N}-\{2-[(7-$ chloroquinolin-4yl)amino]ethyl \}ureas. Bioorganic \& Medicinal Chemistry, 2010, 18, 6398-403.

[45] Richard, J.V.; Werbovetz, K.A., New antileishmanial candidates and lead compounds. Current Opinion in Chemical Biology, 2010, 14, 447-55.

[46] Coimbra, E.S.; Carvalhaes, R.; Grazul, R.M.; Machado, P.A.; De Souza, M.V.N.; Da Silva, A.D., Synthesis, Cytotoxicity and Antileishmanial Activity of Some N-(2-(indol-3-yl)ethyl)-7-chloroquinolin-4-amines. Chemical Biology \& Drug Design, 2010, 75, 628-31.

[47] Kaur, K.; Patel, S.R.; Patil, P.; Jain, M.; Khan, S.I.; Jacob, M.R.; Ganesan, S.; Tekwani, B.L.; Jain, R., Synthesis, antimalarial, antileishmanial, antimicrobial, cytotoxicity, and methemoglobin (MetHB) formation activities of new 8quinolinamines. Bioorg. Med. Chem., 2007, 15, 915-30.

[48] Sereno, D.; Lemesre, J.L., Axenically cultured amastigote forms as an in vitro model for investigation of antileishmanial agents. Antimicrob. Agents Chemother., 1997, 41, 972-76.

[49] Jain, M.; Khan, S.I.; Tekwani, B.L.; Jacob, M.R.; Singh, S.; Singh, P.P.; Jain, R., Synthesis, antimalarial, antileishmanial, and antimicrobial activities of some 8quinolinamine analogues. Bioorg. Med. Chem., 2005, 13, 4458-66.

[50] Seifert, K.; Croft, S.L., In vitro and in vivo interactions between miltefosine and other antileishmanial drugs. Antimicrob. Agents Chemother., 2006, 50, 73-79.

[51] Wasunna, M.K.; Rashid, J.R.; Mbui, J.; Kirigi, G.; Kinoti, D.; Lodenyo, H.; Felton, J.M.; Sabin, A.J.; Horton, J., A phase II dose-increasing study of sitamaquine for the treatment of visceral leishmaniasis in Kenya. Am. J. Trop. Med. Hyg., 2005, 73, 871-76.

[52] Jha, T.K.; Sundar, S.; Thakur, C.P.; Felton, J.M.; Sabin, A.J.; Horton, J., A phase II dose-ranging study of sitamaquine for the treatment of visceral leishmaniasis in India. Am. J. Trop. Med. Hyg., 2005, 73, 1005-11.

[53] Duenas-Romero, A.M.; Loiseau, P.M.; Saint-Pierre-Chazalet, M., Interaction of sitamaquine with membrane lipids of Leishmania donovani promastigotes. Biochim. Biophys. Acta, Biomembr., 2007, 1768, 246-52.

[54] Vercesi, A.E.; Docampo, R., Ca2+ transport by digitonin-permeabilized Leishmania donovani. Effects of Ca2+, pentamidine and WR-6026 on mitochondrial membrane potential in situ. Biochem. J., 1992, 284, 463-67.

[55] LaMontagne, M.P.; Dagli, D.; Khan, M.S.; Blumbergs, P., Analogues of 8-[[6(diethylamino) hexyl]amino]-6-methoxy-4-methylquinoline as candidate antileishmanial agents. J. Med. Chem., 1980, 23, 981-5.

[56] Johnson, J.L.; Werbel, L.M., Synthesis and Antileishmanial Activity of 6methoxy-4methyl- $N$-[6-(substituted-1-piperazinyl)hexyl]-8-quinolinamines and Related Compounds. J. Med. Chem., 1983, 26, 185-94.

[57] Scovill, J.P.; Klayman, D.L.; Woods, T.S.; Sweeney, T.R., Primaquine analogues: derivatives of 4-amino-2-methoxyacridine. J. Med. Chem., 1979, 22, 116467.

[58] Tempone, A.G.; Da Silva, A.C.M.P.; Brandt, C.A.; Martinez, F.S.; Borborema, S.E.T.; Da Silveira, M.A.B.; De Andrade, H.F., Jr., Synthesis and antileishmanial activities of novel 3-substituted quinolines. Antimicrob. Agents Chemother., 2005, 49, 1076-80.

[59] St. George, S.; Bishop, J.V.; Titus, R.G.; Selitrennikoff, C.P., Novel compounds active against Leishmania major. Antimicrob. Agents Chemother., 2006, 50, 474-79. 
[60] Shetty, R.V.; Blanton, C.D., Jr., Synthesis of 2-substituted primaquine analogues as potential antimalarials. J. Med. Chem., 1978, 21, 995-98.

[61] Mattock, N.M.; Peters, W., The experimental chemotherapy of leishmaniasis, III. Detection of antileishmanial activity in some new synthetic compounds in a tissue culture model. Ann. Trop. Med. Parasitol., 1975, 69, 449-62.

[62] Peters, W.; Trotter, E.R.; Robinson, B.L., The experimental chemotherapy of leishmaniasis. VII. Drug responses of L. major and L. mexicana amazonensis, with an analysis of promising chemical leads to new antileishmanial agents. Ann. Trop. Med. Parasitol. , 1980, 74, 321-35.

[63] Cheng, C.C.; Yan, S.J., The Friedländer Synthesis of Quinolines. Org. React., 1982, $28,37$.

[64] Martinez, R.; Ramon, D.J.; Yus, M., Transition-Metal-Free Indirect Friedlander Synthesis of Quinolines from Alcohols. J. Org. Chem, 2008, 73, 9778-80. [65] Avula, B.; Tripathi, L.; Khan, S.; Tekwani, B.; Nanayakkara, D.; Gul, W.; ElSohly, M.; Khan, I., LC Method for the Determination of NPC1161, Primaquine and their Metabolites in Various Biological Systems. Chromatographia, 2006, 64, 429-34.

[66] Nan, A.; Croft, S.L.; Yardley, V.; Ghandehari, H., Targetable water-soluble polymer-drug conjugates for the treatment of visceral leishmaniasis. J. Controlled Release, 2004, 94, 115-27.

[67] Jain, M.; Vangapandu, S.; Sachdeva, S.; Singh, S.; Singh, P.P.; Jena, G.B.; Tikoo, K.; Ramarao, P.; Kaul, C.L.; Jain, R., Discovery of a Bulky 2-tert-Butyl Group Containing Primaquine Analogue That Exhibits Potent Blood-Schizontocidal Antimalarial Activities and Complete Elimination of Methemoglobin Toxicity. $J$. Med. Chem., 2004, 47, 285-87.

[68] Brueckner, R.P.; Coster, T.; Wesche, D.L.; Shmuklarsky, M.; Schuster, B.G., Prophylaxis of Plasmodium falciparum Infection in a Human Challenge Model with WR 238605, a New 8-Aminoquinoline Antimalarial. Antimicrob. Agents Chemother., 1998, 42, 1293-94.

[69] Skinner, R.B., Imiquimod. Dermatologic clinics, 2003, 21, 291-300.

[70] Casado, J.L.; Lopez-Velez, R.; Pintado, V.; Quereda, C.; Antela, A.; Moreno, S., Relapsing visceral leishmaniasis in HIV-infected patients undergoing successful protease inhibitor therapy. Eur. J. Clin. Chem. Clin. Microbiol. Infectious Dis., 2001, 20, 202-05.

[71] Trotter, E.R.; Peters, W.; Robinson, B.L., The experimental chemotherapy of leishmaniasis. VI. The development of rodent models for cutaneous infection with $L$. major and L. mexicana amazonensis. Ann. Trop. Med. Parasitol. , 1980, 74, 299-319.

[72] Chapman, W.L.; Hanson, W.L.; Waits, V.B.; Kinnamon, K.E., Antileishmanial activity of selected compounds in dogs experimentally infected with Leishmania donovani. Rev. Inst. Med. Trop. São Paulo, 1979, 21, 189-93.

[73] White, M.R.; Chapman, W.L., Jr.; Hanson, W.L., Chemotherapy of experimental visceral leishmaniasis in the opossum. J. Parasitol., 1989, 75, 176-8.

[74] Levine, B.S.; Furedi-Machacek, E.M.; Brown, A.P.; Tomlinson, M.J., Subchronic toxicity and reversibility of WR6026 dihydrochloride, an 8aminoquinoline antileishmanial drug, in rats and dogs. Drug Dev. Res., 1997, 40, 7587.

[75] Fournet, A.; Angelo Barrios, A.; Munoz, V.; Hocquemiller, R.; Roblot, F.; Bruneton, J.; Richomme, P.; Gantier, J.C. Preparation of 2-substituted quinolines for treating leishmaniasis. . 1993. 
[76] Fournet, A.; Gantier, J.C.; Gautheret, A.; Leysalles, L.; Munos, M.H.; Mayrargue, J.; Moskowitz, H.; Cave, A.; Hocquemiller, R., The activity of 2substituted quinoline alkaloids in BALB/c mice infected with Leishmania donovani. J. Antimicrob. Chemother., 1994, 33, 537-44.

[77] Iglarz, M.; Baune, B.; Gantier, J.C.; Hocquemiller, R.; Farinotti, R., Determination of 2-n-propylquinoline in mouse plasma and liver by high-performance liquid chromatography. J. Chromatogr. B: Biomedical Sciences and Applications, 1998, 714, 335-40.

[78] Buates, S.; Matlashewski, G., Treatment of Experimental Leishmaniasis with the Immunomodulators Imiquimod and Sâ€• 28463: Efficacy and Mode of Action. The Journal of Infectious Diseases, 1999, 179, 1485-94.

[79] Mansour, N.S.; McConnell, E., Leishmaniasis in the Sudan Republic. 27. Lack of effect of chloroquine and pyrimethamine on visceral leishmaniasis in the hamster. Am. J. Trop. Med. Hyg., 1966, 15, 146-48.

[80] Hendrickx, E.P.; Del Pilar Agudelo, S.; Munoz, D.L.; Puerta, J.A.; Bernal, I.D.V., Lack of efficacy of mefloquine in the treatment of New World cutaneous leishmaniasis in Colombia. Am. J. Trop. Med. Hyg., 1998, 59, 889-92.

[81] Gomez Landires, E.A.; Andrial, M.; Hosakawa, A.; Nonaka, S.; Hashiguchi, Y., Oral treatment of New World cutaneous leishmaniasis with anti-malarial drugs in Ecuador: a preliminary clinical trial. Jpn. J. Trop. Med. Hyg., 1995, 23, 151-57.

[82] Guderian, R.H.; Chico, M.E.; Rogers, M.D.; Pattishall, K.M.; Grogl, M.; Berman, J.D., Placebo Controlled Treatment of Ecuadorian Cutaneous Leishmaniasis. Am J Trop Med Hyg, 1991, 45, 92-97.

[83] Seeberger, J.; Daoud, S.; Pammer, J., Transient effect of topical treatment of cutaneous leishmaniasis with imiquimod. International Journal of Dermatology, 2003, 42, 576-79.

[84] Arevalo, I.; Ward, B.J.; Miller, R.; Meng, T.C.; Najar, E.; Alvarez, E.; Matlashewski, G.; Llanos Cuentas, A., Successful Treatment of Drugâ€• Resistant Cutaneous Leishmaniasis in Humans by Use of Imiquimod, an Immunomodulator. Clinical Infectious Diseases, 2001, 33, 1847-51.

[85] Miranda Verástegui, C.; Llanos Cuentas, A.; Arévalo, I.; Ward, B.J.; Matlashewski, G., Randomized, Double Blind Clinical Trial of Topical Imiquimod 5\% with Parenteral Meglumine Antimoniate in the Treatment of Cutaneous Leishmaniasis in Peru. Clinical Infectious Diseases, 2005, 40, 1395-403.

[86] Alving, A.S.; Arnold, J.; Hockwald, R.S.; Clayman, C.B.; Dern, R.J.; Beutler, E.; Flanagan, C.L., Potentiation of the curative action of primaquine in vivax malaria by quinine and chloroquine. J. Lab. Clin. Med., 1955, 46, 301-06

[87] Hill, D.R.; Baird, J.K.; Parise, M.E.; Lewis, L.S.; Ryan, E.T.; Magill, A.J., Primaquine: Rreport from CDC Expert Meeting on Malaria Chemoprophylaxis I. Am. J. Trop. Med. Hyg., 2006, 75, 402-15.

[88] Bryceson, A.D., Diffuse cutaneous leishmaniasis in Ethiopia. II. Treatment. Trans. R. Soc. Trop. Med. Hyg., 1970, 64, 369-79.

[89] Talati, S.M.; Latham, M.R.; Moore, E.G.; Hargreaves, G.W.; Blanton, C.D.J., J. Pharm. Sci., 1970, 59, 491.

[90] Shetty, R.V.; Wetter, W.P.; Blanton, C.D., Synthesis of 2-benzyloxy and 2benzylthio analogs of primaquine as potential antimalarials. Journal of Medicinal Chemistry, 1977, 20, 1349-51. 
[91] Beveridge, E.; Caldwell, I.C.; Latter, V.S.; Neal, R.A.; Udall, V.; Waldron, M.M., The activity against Trypanosoma cruzi and cutaneous leishmaniasis, and toxicity, of moxipraquine (349C59). Trans. R. Soc. Trop. Med. Hyg., 1980, 74, 43-51. [92] Burghard, H.; DeWitt Blanton, C., Jr., 4,5-disubstituted primaquine analogs as potential antiprotozoan agents. J. Pharm. Sci., 1980, 69, 933-36.

[93] Kinnamon, K.E. Anti-leishmanial lepidine derivatives. 1980.

[94] New, R.R.C.; Chance, M.L.; Heath, S., Liposome therapy for experimental cutaneous and visceral leishmaniasis. Biol. Cell., 1983, 47, 59-64.

[95] Steck, E.A.; Alving, C.R. Liposome Carriers in Leishmaniasis Chemotherapy with 8-Aminoquinoline Derivatives. 1981.

[96] Rodrigues, J.M., Jr.; Croft, S.L.; Fessi, H.; Bories, C.; Devissaguet, J.P., The activity and ultrastructural localization of primaquine-loaded poly (d,l-lactide) nanoparticles in Leishmania donovani infected mice. Trop. Med. Parasitol., 1994, 45, 223-28.

[97] Nishi, K.K.; Jayakrishnan, A., Self-Gelling Primaquine-Gum Arabic Conjugate: An Injectable Controlled Delivery System for Primaquine. Biomacromolecules, 2007, 8, 84-90.

[98] Gaspar, R.; Preat, V.; Roland, M., Nanoparticles of poly(isohexyl cyanoacrylate) (PIHCA) as carriers of primaquine: formulation, physicochemical characterization and acute toxicity. Int. J. Pharm., 1991, 68, 111-19.

[99] Gaspar, R.; Opperdoes, F.R.; Preat, V.; Roland, M., Drug targeting with poly(alkyl cyanoacrylate) nanoparticles: in vitro activity of primaquine-loaded nanoparticles against intracellular Leishmania donovani. Ann. Trop. Med. Parasitol., 1992, 86, 41-9.

[100] Rodrigues, J.M.; Fessi, H.; Bories, C.; Puisieux, F.; Devissaguet, J.p., Primaquine-loaded poly(lactide) nanoparticles: physicochemical study and acute tolerance in mice. Int. J. Pharm., 1995, 126, 253-60.

[101] Stjaernkvist, P., Biodegradable microspheres: XIV. Effect of microparticlebound primaquine on Leishmania donovani in mice. Int. J. Pharm., 1993, 96, 23-32.

[102] Banerjee, G.; Medda, S.; Basu, M.K., A novel peptide-grafted liposomal delivery system targeted to macrophages. Antimicrob. Agents Chemother., 1998, 42, 348-51.

[103] Yeates, C., Sitamaquine GlaxoSmithKline/Walter Reed Army Institute. Curr. Opin. Infect. Dis., 2002, 3, 1446-52.

[104] Neal, R.A.; Croft, S.L.; Nelson, D.J., Anti-leishmanial effect of allopurinol ribonucleoside and the related compounds, allopurinol, thiopurinol, thiopurinol ribonucleoside, and of formycin $\mathrm{B}$, sinefungin and the lepidine WR6026. Trans. $R$. Soc. Trop. Med. Hyg., 1985, 79, 122-8.

[105] Kinnamon, K.E.; Steck, E.A.; Loizeaux, P.S.; Chapman, W.L., Jr.; Waits, V.B.; Hanson, W.L., Leishmaniasis: in search of new chemotherapeutic agents. Am. J. Vet. Res., 1980, 41, 405-07.

[106] Carroll, F.I.; Berrang, B.D.; Linn, C.P., Synthesis of 2,4-disubstituted 6methoxy-8-aminoquinoline analogs as potential antiparasitics. J. Med. Chem., 1980, $23,581-84$.

[107] Nanayakkara, N.P.D.; Ager, A.L., Jr.; Bartlett, M.S.; Yardley, V.; Croft, S.L.; Khan, I.A.; McChesney, J.D.; Walker, L.A., Antiparasitic Activities and Toxicities of Individual Enantiomers of the 8-Aminoquinoline 8-[(4-Amino-1Methylbutyl)Amino]-6-Methoxy-4-Methyl-5-[3,4-Dichlorophenoxy]Quinoline Succinate. Antimicrob. Agents Chemother., 2008, 52, 2130-37.

[108] Werbel, L.M.; Steck, E.A. Anti-leishmanial lepidine derivatives 1987. 
[109] Garnier, T.; Brown, M.B.; Lawrence, M.J.; Croft, S.L., In-vitro and in-vivo studies on a topical formulation of sitamaquine dihydrochloride for cutaneous leishmaniasis. J. Pharm. Pharmacol., 2006, 58, 1043-54.

[110] Alving, C.R.; Steck, E.A.; Chapman, W.L., Jr.; Waits, V.B.; Hendricks, L.D.; Swartz, G.M., Jr.; Hanson, W.L., Liposomes in leishmaniasis: therapeutic effects of antimonial drugs, 8-aminoquinolines, and tetracycline. Life Sci., 1980, 26, 2231-38.

[111] Steck, E.A., The chemotherapy of protozoal infections: whither? J. Protozool., 1981, 28, 30-5.

[112] Nan, A.; Nanayakkara, N.P.D.; Walker, L.A.; Yardley, V.; Croft, S.L.; Ghandehari, H., N-(2-hydroxypropyl)methacrylamide (HPMA) copolymers for targeted delivery of 8-aminoquinoline antileishmanial drugs. J. Controlled Release, 2001, 77, 233-43.

[113] Theoharides, A.D.; Chungm, H.; Velazquez, H., Fed. Proc. Fed. Am. Socs exp. Biol., 1983, 42, 4.

[114] Theoharides, A.D.; Kim, M.M.; Ashmore, R.W.; Shipley, L.A., Fed. Proc. Fed. Am. Socs exp. Biol., 1987, 46, 865.

[115] Sundar, S., Drug resistance in Indian visceral leishmaniasis. Trop. Med. Int. Health, 2001, 6, 849-54.

[116] Singh, R.K.; Pandey, H.P.; Sundar, S., Visceral leishmaniasis (kala-azar): challenges ahead. Indian J. Med. Res., 2006, 123, 331-44.

[117] Guerin, P.J.; Olliaro, P.; Sundar, S.; Boelaert, M.; Croft, S.L.; Desjeux, P.; K., W.M.; Bryceson, A.D.M., Visceral leishmaniasis: current status of control, diagnosis, and treatment, and a proposed research and development agenda. Lancet Infect. Dis., 2002, 2, 494-501.

[118] Sherwood, J.A.; Gachihi, G.S.; Muigai, R.K.; Skillman, D.R.; Mugo, M.; Rashid, J.R.; Wasunna, K.M.; Were, J.B.; Kasili, S.K.; Mbugua, J.M., Phase 2 efficacy trial of an oral 8-aminoquinoline (WR6026) for treatment of visceral leishmaniasis. Clin. Infect. Dis., 1994, 19, 1034-9.

[119] Dietze, R.; Carvalho, S.F.G.; Valli, L.C.; Berman, J.; Brewer, T.; Milhous, W.; Sanchez, J.; Schuster, B.; Grogl, M., Phase 2 trial of WR6026, an orally administered 8 -aminoquinoline, in the treatment of visceral leishmaniasis caused by Leishmania chagasi. Am. J. Trop. Med. Hyg., 2001, 65, 685-89.

[120] Rashid, J.R.; Nyakundi, P.M.; Kirigi, G.; Kinoti, D.; Wasunna, M.K. Compassionate use of sitamaquine in an HIV-positive patient with visceral leishmaniasis; Kenya Medical Research Institute, Centre for Clinical Research, P.O. Box 20778, Nairobi, Kenya: England: United Kingdom, 2002; pp 533-4. 